University of Nebraska - Lincoln

DigitalCommons@University of Nebraska - Lincoln

$10-21-2002$

\title{
Phase and amplitude of ecosystem carbon release and uptake potentials as derived from FLUXNET measurements
}

\author{
Eva Falge \\ Pflanzenökologie, Universität Bayreuth \\ John Tenhunen \\ Pflanzenökologie, Universität Bayreuth \\ Dennis D. Baldocchi \\ University of California, Berkeley, baldocchi@berkeley.edu \\ Marc Aubinet \\ Faculté des Sciences Agronomiques de Gembloux, Unité de Physique, B-5030 Gembloux, Belgium \\ Peter Bakwin \\ NOAA/OAR, Climate Monitoring and Diagnostics Laboratory \\ Follow this and additional works at: https://digitalcommons.unl.edu/natrespapers \\ See next page for additional authors \\ Part of the Natural Resources and Conservation Commons
}

Falge, Eva; Tenhunen, John; Baldocchi, Dennis D.; Aubinet, Marc; Bakwin, Peter; Berbigier, Paul; Bernhofer, Christian; Bonnefond, Jean-Marc; Burba, George; Clement, Robert; Davis, Kenneth J.; Elbers, Jan A.; Falk, Matthias; Goldstein, Allen H.; Grelle, Achim; Granier, Andre; Grunwald, Thomas; Gundmondsson, Jon; Hollinger, David; Janssens, Ivan A.; Keronen, Petri; Kowalski, Andrew S.; Katul, Gabriel; Law, Beverly E.; Malhi, Yadvinder; Meyers, Tilden; Monson, Russell K.; Moors, Eddy; Munger, J. William; Oechel, Walt; Paw U, KyawTha; Pilegaard, Kim; Rannik, Ullar; Rebmann, Corinna; Suyker, Andrew E.; Thorgeirsson, Halldor; Tirone, Giampiero; Turnipseed, Andrew; Wilson, Kell; and Wofsy, Steve, "Phase and amplitude of ecosystem carbon release and uptake potentials as derived from FLUXNET measurements" (2002). Papers in Natural Resources. 60.

https://digitalcommons.unl.edu/natrespapers/60

This Article is brought to you for free and open access by the Natural Resources, School of at DigitalCommons@University of Nebraska - Lincoln. It has been accepted for inclusion in Papers in Natural Resources by an authorized administrator of DigitalCommons@University of Nebraska - Lincoln. 


\section{Authors}

Eva Falge, John Tenhunen, Dennis D. Baldocchi, Marc Aubinet, Peter Bakwin, Paul Berbigier, Christian Bernhofer, Jean-Marc Bonnefond, George Burba, Robert Clement, Kenneth J. Davis, Jan A. Elbers, Matthias Falk, Allen H. Goldstein, Achim Grelle, Andre Granier, Thomas Grunwald, Jon Gundmondsson, David Hollinger, Ivan A. Janssens, Petri Keronen, Andrew S. Kowalski, Gabriel Katul, Beverly E. Law,

Yadvinder Malhi, Tilden Meyers, Russell K. Monson, Eddy Moors, J. William Munger, Walt Oechel, KyawTha Paw U, Kim Pilegaard, Ullar Rannik, Corinna Rebmann, Andrew E. Suyker, Halldor Thorgeirsson, Giampiero Tirone, Andrew Turnipseed, Kell Wilson, and Steve Wofsy 


\section{Phase and amplitude of ecosystem carbon release and uptake potentials as derived from FLUXNET measurements ${ }^{\text {th }}$}

Eva Falge ${ }^{\mathrm{a}, *}$, John Tenhunen ${ }^{\mathrm{a}}$, Dennis Baldocchi ${ }^{\mathrm{b}}$, Marc Aubinet ${ }^{\mathrm{c}}$, Peter Bakwin ${ }^{\mathrm{d}}$, Paul Berbigier ${ }^{\mathrm{p}}$, Christian Bernhofer ${ }^{\mathrm{k}}$, Jean-Marc Bonnefond ${ }^{\mathrm{p}}$, George Burba $^{\mathrm{e}}$, Robert Clement ${ }^{\mathrm{f}}$, Kenneth J. Davis ${ }^{\mathrm{g}}$, Jan A. Elbers ${ }^{\mathrm{s}}$, Matthias Falk ${ }^{\mathrm{h}}$, Allen H. Goldstein ${ }^{\mathrm{b}}$, Achim Grelle ${ }^{\mathrm{i}}$, André Granier ${ }^{\mathrm{j}}$, Thomas Grünwald ${ }^{\mathrm{k}}$, Jón Guððmundsson ${ }^{y}$, David Hollinger ${ }^{1}$, Ivan A. Janssens ${ }^{\mathrm{m}}$, Petri Keronen ${ }^{\mathrm{w}}$, Andrew S. Kowalski ${ }^{\mathrm{m}}$, Gabriel Katul ${ }^{\mathrm{n}}$, Beverly E. Law ${ }^{\mathrm{o}}$, Yadvinder Malhi ${ }^{\mathrm{f}}$, Tilden Meyers $^{\mathrm{q}}$, Russell K. Monson ${ }^{\mathrm{r}}$, Eddy Moors ${ }^{\mathrm{s}}$, J. William Munger ${ }^{\mathrm{t}}$, Walt Oechel $^{\text {u }}$, Kyaw Tha Paw $\mathrm{U}^{\mathrm{h}}$, Kim Pilegaard ${ }^{\mathrm{v}}$, Üllar Rannik ${ }^{\mathrm{w}}$, Corinna Rebmann ${ }^{\mathrm{x}}$, Andrew Suyker ${ }^{\mathrm{e}}$, Halldor Thorgeirsson ${ }^{\mathrm{y}}$, Giampiero Tirone ${ }^{\mathrm{z}}$, Andrew Turnipseed ${ }^{\mathrm{r}}$, Kell Wilson ${ }^{\mathrm{q}}$, Steve Wofsy ${ }^{\mathrm{t}}$

${ }^{a}$ Pflanzenökologie, Universität Bayreuth, 95440 Bayreuth, Germany

${ }^{\mathrm{b}}$ ESPM, University of California, Berkeley, CA 94720, USA

${ }^{\mathrm{c}}$ Faculté des Sciences Agronomiques de Gembloux, Unité de Physique, B-5030 Gembloux, Belgium

d NOAA/OAR, Climate Monitoring and Diagnostics Laboratory, 325 Broadway, Boulder, CO 80303, USA

e School of Natural Resource Sciences, 244 L.W. Chase Hall, P.O. Box 830728, University of Nebraska-Lincoln, Lincoln, NE 68583-0728, USA

${ }^{\mathrm{f}}$ Institute of Ecology and Resource Management, University of Edinburgh, Darwin Building, The King's Buildings, Mayfield Road, Edinburgh EH9 3JU, UK

g Department of Meteorology, The Pennsylvania State University, University Park, PA 16802, USA

${ }^{\mathrm{h}}$ Atmospheric Science Group, LAWR, UC Davis, 122 Hoagland Hall, Davis, CA 95616, USA

${ }^{i}$ Department of Ecology and Environmental Research, Swedish University of Agricultural Sciences, S-75007 Uppsala, Sweden

j INRA, Unité d'Ecophysiologie Forestière, F-54280 Champenoux, France

${ }^{\mathrm{k}}$ Technische Universität Dresden, IHM Meteorologie, Pienner Str. 9, 01737 Tharandt, Germany

${ }^{1}$ USDA Forest Service, 271 Mast Rd, Durham, NH 03824, USA

${ }^{\mathrm{m}}$ Department of Biology, Research Group of Plant and Vegetation Ecology, University of Antwerpen, Universiteitsplein 1, B-2610, Wilrijk, Antwerp, Belgium

${ }^{\mathrm{n}}$ School of the Environment, Box 90328, Duke University, Durham, NC 27708-0328, USA

${ }^{\circ}$ Richardson Hall, Oregon State University, Corvallis, OR 97331-2209, USA

p INRA, Bioclimatologie, Bordeaux, France

${ }^{\mathrm{q}}$ NOAA/ATDD, 456 S. Illinois Avenue, Oak Ridge, TN 37831-2456, USA

${ }^{\mathrm{r}}$ Department of Environmental, Population, and Organismic Biology, University of Colorado, Campus Box 334, Boulder, CO 80309, USA ${ }^{s}$ Alterra, Postbus 47, 6700 AA Wageningen, The Netherlands

${ }^{\mathrm{t}}$ Department of Earth and Planetary Sciences, Harvard University, 20 Oxford St., Cambridge, MA 02138, USA

Accepted 3 April 2002

\footnotetext{
* Corresponding author. Tel.: +49-921-55-2576; fax: +49-921-55-2564.

E-mail address: falge@uni-bayreuth.de (E. Falge).

Special Issue FLUXNET Synthesis Workshop, Marconi Conference Center, June 2000.
} 


\author{
u Department of Biology, San Diego State University, San Diego, CA 92182, USA \\ ${ }^{v}$ Plant Biology and Biogeochemistry Department, Risoe National Laboratory, \\ P.O. Box 49, DK-4000 Roskilde, Denmark \\ ${ }^{w}$ Department of Physics, P.O. Box 9, University of Helsinki, FIN-00014 Helsinki, Finland \\ ${ }^{x}$ Max-Planck-Institut für Biogeochemie, Tatzendpromenade 1a, 07701 Jena, Germany \\ ${ }^{y}$ Department of Environmental Research, Agricultural Research Institute, Keldnaholti, IS-112 Reykjavik, Iceland \\ ${ }^{\mathrm{z}}$ Department of Forest Environment and Resources, University of Tuscia, I-01100 Viterbo, Italy
}

\begin{abstract}
As length and timing of the growing season are major factors explaining differences in carbon exchange of ecosystems, we analyzed seasonal patterns of net ecosystem carbon exchange $\left(F_{\mathrm{NEE}}\right)$ using eddy covariance data of the FLUXNET data base (http://www-eosdis.ornl.gov/FLUXNET). The study included boreal and temperate, deciduous and coniferous forests, Mediterranean evergreen systems, rainforest, native and managed temperate grasslands, tundra, and $\mathrm{C}_{3}$ and $\mathrm{C}_{4}$ crops. Generalization of seasonal patterns are useful for identifying functional vegetation types for global dynamic vegetation models, as well as for global inversion studies, and can help improve phenological modules in SVAT or biogeochemical models. The results of this study have important validation potential for global carbon cycle modeling.

The phasing of respiratory and assimilatory capacity differed within forest types: for temperate coniferous forests seasonal uptake and release capacities are in phase, for temperate deciduous and boreal coniferous forests, release was delayed compared to uptake. According to seasonal pattern of maximum nighttime release (evaluated over 15-day periods, $F_{\max }$ ) the study sites can be grouped in four classes: (1) boreal and high altitude conifers and grasslands; (2) temperate deciduous and temperate conifers; (3) tundra and crops; (4) evergreen Mediterranean and tropical forests. Similar results are found for maximum daytime uptake $\left(F_{\min }\right)$ and the integral net carbon flux, but temperate deciduous forests fall into class 1 .

For forests, seasonal amplitudes of $F_{\max }$ and $F_{\min }$ increased in the order tropical $<$ Mediterranean and temperate coniferous $<$ temperate deciduous and boreal forests, and the pattern seems relatively stable for these groups. The seasonal amplitudes of $F_{\max }$ and $F_{\min }$ are largest for managed grasslands and crops. Largest observed values of $F_{\min }$ varied between -48 and $-2 \mu \mathrm{mol} \mathrm{m}{ }^{-2} \mathrm{~s}^{-1}$, decreasing in the order $\mathrm{C}_{4}$-crops $>\mathrm{C}_{3}$-crops $>$ temperate deciduous forests $>$ temperate conifers $>$ boreal conifers $>$ tundra ecosystems.

Due to data restrictions, our analysis centered mainly on Northern Hemisphere temperate and boreal forest ecosystems. Grasslands, crops, Mediterranean ecosystems, and rainforests are under-represented, as are savanna systems, wooded grassland, shrubland, or year-round measurements in tundra systems. For regional or global estimates of carbon sequestration potentials, future investigations of eddy covariance should expand in these systems.
\end{abstract}

(C) 2002 Elsevier Science B.V. All rights reserved.

Keywords: Growing season length; Net ecosystem $\mathrm{CO}_{2}$ exchange; FLUXNET; EUROFLUX; AmeriFlux; Eddy covariance

\section{Introduction}

Seasonal changes in ecosystem fluxes occur in response to meteorological conditions and physiological activity, which in turn are governed by the seasonal progressive shift in climate. Seasonal changes in net ecosystem exchange $\left(F_{\mathrm{NEE}}\right)$ reveal information about the length of the active period for the component processes, photosynthesis and respiration, as well as their relative strengths. Day-to-day variation in $F_{\mathrm{NEE}}$ depend on the amplitude of photosynthetic carbon uptake and respiration losses, and in literature, maximum values of carbon uptake have been considered useful measures to quantify ecosystem function across vegetation types (Buchmann and Schulze, 1999). In conclusion, the seasonal phasing and amplitude of net ecosystem $\mathrm{CO}_{2}$ fluxes determine the seasonality of the carbon sequestration potential of any ecosystem.

The importance of the length of the growing season for ecosystem carbon balances has been illustrated in numerous studies, e.g., differences in $F_{\mathrm{NPP}}$ (ecosystem net primary production) of Siberian and European forests are attributed to changes in growing season length, climate and nutrition (Schulze et al., 1999). Interannual variability in growing season length may even determine whether boreal and arctic systems are 
a net sink or a net source of carbon (Black et al., 1996; Goulden et al., 1998; Black et al., 2000). The same result occurs in response to the presence or absence of summer drought in grasslands (Meyers, 2001). Furthermore, as a result of global warming, systematic changes in the length of the growing season are expected (Houghton et al., 1996). Additionally, recent modeling results suggest that a 5-10-day lengthening of the growing season should increase net productivity of some forests by as much as one-third (Jackson et al., 2000).

Numerous investigations have examined the phase and amplitude of seasonal cycles in $\mathrm{CO}_{2}$ flux with indirect methods (Keeling et al., 1996; Myneni et al., 1997; Hasenauer et al., 1999; Menzel and Fabian, 1999; Randerson et al., 1999; Keyser et al., 2000). Growing season lengths have been assessed by observing the atmospheric $\mathrm{CO}_{2}$ cycle, where biological activity is inferred from changes in $\mathrm{CO}_{2}$ concentration in air (Ciais et al., 1995; Enting et al., 1995; Fan et al., 1998; Bousquet et al., 1999; Rayner et al., 1999; Peylin et al., 1999). Other studies have relied on the normalized difference vegetation index (NDVI) records, or on phenological data.

$\mathrm{CO}_{2}$ fluxes from the land surface into the atmosphere as measured by eddy covariance approaches can provide direct estimates of the phasing and amplitude of ecosystem processes and help address interannual variability in growing season lengths and their effects on ecosystem processes. Flux tower networks now provide $F_{\mathrm{NEE}}$ monitoring over a wide range of vegetation and climatic zones: deciduous and coniferous forests, crops, and grasslands located in boreal, temperate, Mediterranean and tropical climate zones of the European and Northern American continents. Since the timing of physiological activity in ecosystems is largely governed by the onset and duration of seasonal shifts in climate, and ecosystem fluxes are a response to integrated meteorological conditions, eddy covariance approaches together with micrometeorological measurements provide valuable insights about seasonal phasing and amplitudes of ecosystem fluxes. Utilizing the FLUXNET data base (Baldocchi et al., 2001), a data base of qualified flux and meteorological data, we have quantified carbon uptake and release patterns in order to evaluate carbon sequestration potentials across ecosystems.
Many attempts have been made to classify biological systems according to functional criteria, e.g., plant functional types (Smith et al., 1997), or vegetation functional types (Grime, 1993; Solomon and Shugart, 1993). Differentiation into "types" assumes similarities in plant or ecosystem functions and structures (e.g., Körner, 1994; Walker, 1997; Woodward and Kelly, 1997). With respect to ecosystem carbon fluxes, the relevant "functions" are photosynthesis, respiration, and allocation patterns. Studies focussing on the energy exchange between the surface and the atmosphere could use different classification schemes based on roughness length, vegetation cover, or stomatal conductance (biosphere-atmosphere transfer schemes; Sellers et al., 1996). In model applications, the efficiency or usefulness of a vegetation classification may be evaluated in terms of the plausibility of the model results, that eventually depend on the a priori classification itself. We believe that the results presented here will help to contribute to the refinement of vegetation functional types, that are needed for regional up-scaling or inversion approaches.

Characterization of seasonal phasing and amplitudes of ecosystem fluxes is important for assessing regional or global carbon sequestration potentials and for understanding the controls that govern the interplay between respiratory and assimilatory processes. Data on seasonal amplitudes of $\mathrm{CO}_{2}$ fluxes, i.e., the seasonal development of maximum carbon uptake and release capacity of ecosystems, are important information for the parameterization and validation of soil-vegetation-atmosphere transfer (SVAT) models. Data on the seasonal phasing of $\mathrm{CO}_{2}$ fluxes are needed for the development of improved carbon cycle models focused on either global, regional or plot scales, and for SVAT modelers interested in longer-term or regional applications. To assess accurately long-term climate warming effects, carbon cycle models need to take into account dynamic, climatically controlled growing season length (White et al., 1997, 1999), phenological events, such as leaf development and senescence, or changes in photosynthetic capacity (Oberbauer et al., 1998; Starr et al., 2000). Analysis of yearlong eddy covariance data can help establish long-term changes in the length of the active period and seasonal patterns of photosynthetic or respiratory capacity. 
In this study we describe the phasing and amplitude of net ecosystem exchange of carbon dioxide $\left(F_{\mathrm{NEE}}\right)$, and key meteorological variables obtained from eddy covariance tower networks. We examine mean diurnal variations of $F_{\mathrm{NEE}}$ over the course of the year and derive seasonal patterns for maximum carbon uptake and release. Assessing nighttime and daytime seasonal patterns separately, we discuss the changes in the relative contribution of respiratory and total ecosystem activity from a variety of vegetation types of the Northern Hemisphere. The goals of this study are to quantify location, vegetation and climate of the sites, and give references to more detailed studies at the sites.

Flux measurements were obtained for 16 EUROFLUX sites with 2-4 years of data collected between 1996 and 2000 and 23 AmeriFlux sites with 1-8 years of data collected between 1992 and 2000 resulting in a total of 104 unique site-year combinations (Table 1a and $b$ ).

To assess phasing and amplitude of $F_{\mathrm{NEE}}$, we calculated in a first step the bin-averages of half-hours for periods of 15 days, as follows:

$$
\overline{X_{h, i}}=\begin{array}{cccc}
\overline{X_{1, k=1, \ldots, n}} & \overline{X_{2, k=1, \ldots, n}} & \ldots & \overline{X_{48, k=1, \ldots, n}} \\
\overline{X_{1, k=2, \ldots, n+1}} & \overline{X_{2, k=2, \ldots, n+1}} & \ldots & \overline{X_{48, k=2, \ldots, n+1}} \\
\vdots & \vdots & \ldots & \vdots \\
\hline X_{1, k=d-n+1, \ldots, d} & X_{2, k=d-n+1, \ldots, d} & \ldots & \overline{X_{48, k=d-n+1, \ldots, d}}
\end{array}
$$

across ecosystem functional types and climates: (1) the length of the net carbon uptake period; (2) minimum, mean and maximum observed $F_{\mathrm{NEE}}$; (3) their seasonal variability and phasing; and (4) the resulting net carbon sequestration of those ecosystems. Phasing and amplitude of $F_{\mathrm{NEE}}$ are analyzed to evaluate whether observed "functional" patterns (in terms of carbon fluxes) are supported by the well-known classification of ecosystems into "vegetation functional types".

\section{Data base and methods}

We utilize FLUXNET data (Baldocchi et al., 2001a), a data base obtained from the data sets of the EUROFLUX (Valentini, 2002) and AmeriFlux projects, a community effort to collect continuous measurements of ecosystem carbon and energy exchange to understand the controls on carbon fluxes (Running et al., 1999). The records cover multiple years of eddy covariance and key meteorological measurements. The data undergo quality assurance, and data gaps are filled using standardized methods to provide complete data sets (Falge et al., 2001b). To allow fast access to multiple records, the data are stored in a unified format, and available in daily, weekly, monthly, and annual time resolution for a variety of potential uses (http://www-eosdis.ornl.gov/FLUXNET). The data base is completed with ancillary data describing where $h$ is the index for the half-hour $(h=1, \ldots, 48)$, $i$ the index for the averaging window with $i=$ $1, \ldots,(d-n+1), d$ the number of days per year, and $n$ the window size (here 15 ; for a variety of ecosystems, fluxes show a spectral gap along this time frame and give reason to bin over 15 days, Baldocchi et al., 2001). Overbar indicates averaging of the data subspace, and $X$ the respective data variable. $F_{\mathrm{NEE}}$ data sets were filled beforehand by look-up table methods for $F_{\mathrm{NEE}}$ during assorted meteorological conditions (see Falge et al., 2001b). This procedure resulted in a time series with a 15-day running mean filter for each half-hour of the day. In a second step for each diurnal course the maximum of the nighttime means, and the maximum of the daytime means were determined for estimates of maximum $\mathrm{CO}_{2}$ release $\left(F_{\max }\right)$, and maximum $\mathrm{CO}_{2}$ uptake $\left(F_{\min }\right)$, respectively (Fig. 1$)$. The day on which these values are plotted in the following are in the middle of each period.

Mean diurnal variations of air temperature $\left(T_{\mathrm{a}}\right)$ and incident radiation $\left(Q_{\mathrm{P}}\right)$ were calculated similarly over the course of the year, and minimum nighttime $T_{\mathrm{a}}$, maximum daytime $T_{\mathrm{a}}$, and maximum daytime $Q_{\mathrm{P}}$ were determined.

The uncertainty of these estimates was assessed according to Moncrieff et al. (1996) as follows. Assuming a random error of $15 \%$ due to the stochastic nature of one-point eddy covariance measurements, the error of typical single day sums of $F_{\mathrm{NEE}}$ fluxes 
Table 1

Site information for forest, agriculture and grassland sites from the EUROFLUX and AmeriFlux projects and several years ${ }^{\mathrm{a}}$

\begin{tabular}{|c|c|c|c|c|c|}
\hline Site & State/country & Period & Abbreviations & Coordinates & Species \\
\hline \multicolumn{6}{|l|}{ (a) Forest sites } \\
\hline \multicolumn{6}{|l|}{ Evergreen forests } \\
\hline \multicolumn{6}{|c|}{ Boreal evergreen conifers (BEC) } \\
\hline North Boreas ${ }^{\mathrm{b}}$ & Man./Canada & 1994-1998 & NB & $55^{\circ} 54^{\prime} \mathrm{N}, 98^{\circ} 30^{\prime} \mathrm{W}$ & Black spruce \\
\hline Flakaliden $^{c}$ & Sweden & $1996-1998$ & FL & $64^{\circ} 07^{\prime} \mathrm{N}, 19^{\circ} 27^{\prime} \mathrm{E}$ & Norway spruce \\
\hline Norunda $^{c}$ & Sweden & 1996-1998 & NO & $60^{\circ} 05^{\prime} \mathrm{N}, 17^{\circ} 28^{\prime} \mathrm{E}$ & Norway spruce, Scots pine \\
\hline Hyytiala $^{c}$ & Finland & 1996-1999 & HY & $61^{\circ} 51^{\prime} \mathrm{N}, 24^{\circ} 17^{\prime} \mathrm{E}$ & Scots pine \\
\hline \multicolumn{6}{|c|}{ Cold temperate evergreen conifers (cTEC) } \\
\hline Niwot Ridge ${ }^{\mathrm{b}}$ & $\mathrm{CO} / \mathrm{USA}$ & 1999-2000 & NR & $40^{\circ} 02^{\prime} \mathrm{N}, 105^{\circ} 33^{\prime} \mathrm{W}$ & $\begin{array}{l}\text { Engelman spruce, } \\
\text { Lodgepole pine, } \\
\text { Subalpine fir }\end{array}$ \\
\hline Howland ${ }^{b}$ & ME/USA & 1996-1997 & $\mathrm{HL}$ & $45^{\circ} 15^{\prime} \mathrm{N}, 68^{\circ} 45^{\prime} \mathrm{W}$ & Spruce-hemlock \\
\hline Weidenbrunnen $^{\mathrm{c}}$ & Germany & 1996-1998 & WE & $50^{\circ} 09^{\prime} \mathrm{N}, 11^{\circ} 52^{\prime} \mathrm{E}$ & Norway spruce \\
\hline \multicolumn{6}{|c|}{ Temperate evergreen conifers (TEC) } \\
\hline Wind River ${ }^{\mathrm{b}}$ & WA/USA & 1998-1999 & WR & $45^{\circ} 49^{\prime} \mathrm{N}, 121^{\circ} 58^{\prime} \mathrm{W}$ & $\begin{array}{l}\text { Douglas fir, Western } \\
\text { hemlock, Pacific } \\
\text { silver fir, Grand fir }\end{array}$ \\
\hline Aberfeldy ${ }^{c}$ & UK & $1996-1998$ & $\mathrm{AB}$ & $56^{\circ} 37^{\prime} \mathrm{N}, 3^{\circ} 48^{\prime} \mathrm{W}$ & Sitka spruce \\
\hline Tharandt ${ }^{\mathrm{c}}$ & Germany & $1996-2000$ & $\mathrm{TH}$ & $50^{\circ} 58^{\prime} \mathrm{N}, 13^{\circ} 40^{\prime} \mathrm{E}$ & Norway spruce \\
\hline Loobos ${ }^{c}$ & The Netherlands & $1996-1998$ & LO & $52^{\circ} 10^{\prime} \mathrm{N}, 5^{\circ} 45^{\prime} \mathrm{E}$ & Scots pine \\
\hline Brasschaat ${ }^{\mathrm{c}}$ & Belgium & $1996-1998$ & $\mathrm{BR}$ & $51^{\circ} 18^{\prime} \mathrm{N}, 4^{\circ} 31^{\prime} \mathrm{E}$ & Scots pine, Oaks \\
\hline Metolius $^{b}$ & OR/USA & $1996-1997$ & ME & $44^{\circ} 30^{\prime} \mathrm{N}, 121^{\circ} 37^{\prime} \mathrm{W}$ & Ponderosa pine \\
\hline \multicolumn{6}{|c|}{ Warm temperate evergreen conifers (wTEC) } \\
\hline Duke Forest ${ }^{\mathrm{b}}$ & NC/USA & $1998-1999$ & DU & $35^{\circ} 52^{\prime} \mathrm{N}, 79^{\circ} 59^{\prime} \mathrm{W}$ & Loblolly pine \\
\hline \multicolumn{6}{|c|}{ Mediterranean evergreen forests (ME) } \\
\hline Castelporziano $^{c}$ & Italy & 1997-1998 & $\mathrm{CP}$ & $41^{\circ} 45^{\prime} \mathrm{N}, 12^{\circ} 22^{\prime} \mathrm{W}$ & Quercus ilex \\
\hline Bordeaux $^{c}$ & France & 1996-1998 & $\mathrm{BO}$ & $44^{\circ} 0^{\prime} \mathrm{N}, 5^{\circ} 0^{\prime} \mathrm{E}$ & Maritime pine \\
\hline Blodgett Forest ${ }^{\mathrm{b}}$ & CA/USA & $1997-2000$ & BL & $38^{\circ} 53^{\prime} \mathrm{N}, 120^{\circ} 37^{\prime} \mathrm{W}$ & Ponderosa pine \\
\hline Sky Oaks young ${ }^{\mathrm{b}}$ & $\mathrm{CA} / \mathrm{USA}$ & 1997-1999 & SKy & $33^{\circ} 22^{\prime} \mathrm{N}, 116^{\circ} 37^{\prime} \mathrm{W}$ & $\begin{array}{l}\text { Adenostoma-ceanothus- } \\
\text { chaparral }\end{array}$ \\
\hline Sky Oaks old ${ }^{\mathrm{b}}$ & $\mathrm{CA} / \mathrm{USA}$ & $1997-1999$ & SKo & $33^{\circ} 22^{\prime} \mathrm{N}, 116^{\circ} 37^{\prime} \mathrm{W}$ & $\begin{array}{l}\text { Adenostoma-ceanothus- } \\
\text { chaparral }\end{array}$ \\
\hline \multicolumn{6}{|c|}{ Tropical evergreen forests (TrE) } \\
\hline Manaus $^{\mathrm{b}}$ & Brazil & $\begin{array}{l}\text { September } \\
\text { 1995-August } 1996\end{array}$ & MA & $-2^{\circ} 36^{\prime} \mathrm{N}, 60^{\circ} 12^{\prime} \mathrm{W}$ & Rainforest \\
\hline \multicolumn{6}{|l|}{ Deciduous forests } \\
\hline \multicolumn{6}{|c|}{ Boreal broad-leaved deciduous (BBD) } \\
\hline Gunnarsholt $^{\mathrm{c}}$ & Iceland & $1996-1998$ & GU & $63^{\circ} 50^{\prime} \mathrm{N}, 20^{\circ} 13^{\prime} \mathrm{W}$ & Poplar \\
\hline \multicolumn{6}{|c|}{ Cold temperate broad-leaved deciduous (cTBD) } \\
\hline Park Falls/WLEF & WI/USA & 1997-1999 & WL & $45^{\circ} 57^{\prime} \mathrm{N}, 90^{\circ} 16^{\prime} \mathrm{W}$ & $\begin{array}{l}\text { Aspen, Mixed } \\
\text { hardwoods oak, Red } \\
\text { pine, Jack pine, } \\
\text { Balsam fir, Bogs/fens }\end{array}$ \\
\hline Willow Creek ${ }^{\mathrm{b}}$ & WI/USA & 1999-2000 & WC & $45^{\circ} 57^{\prime} \mathrm{N}, 90^{\circ} 16^{\prime} \mathrm{W}$ & Deciduous hardwoods \\
\hline \multicolumn{6}{|c|}{ Temperate broad-leaved deciduous (TBD) } \\
\hline Vielsalm $^{c}$ & Belgium & 1996-1998 & VI & $50^{\circ} 18^{\prime} \mathrm{N}, 6^{\circ} 0^{\prime} \mathrm{E}$ & European beech \\
\hline Soroe $^{c}$ & Denmark & 1996-1999 & SO & $55^{\circ} 29^{\prime} \mathrm{N}, 11^{\circ} 39^{\prime} \mathrm{E}$ & European beech \\
\hline Hesse $^{c}$ & France & 1996-1999 & $\mathrm{HE}$ & $48^{\circ} 40^{\prime} \mathrm{N}, 7^{\circ} 50^{\prime} \mathrm{E}$ & European beech \\
\hline Harvard $^{\mathrm{b}}$ & MA/USA & 1992-1999 & $\mathrm{HV}$ & $42^{\circ} 32^{\prime} \mathrm{N}, 72^{\circ} 11^{\prime} \mathrm{W}$ & Oak-maple \\
\hline
\end{tabular}


Table 1 (Continued)

\begin{tabular}{|c|c|c|c|c|c|}
\hline Site & State/country & Period & Abbreviations & Coordinates & Species \\
\hline \multicolumn{6}{|c|}{ Warm temperate broad-leaved deciduous (wTBD) } \\
\hline Walkerbranch $^{\mathrm{b}}$ & TN/USA & $1995-1998$ & WB & $35^{\circ} 58^{\prime} \mathrm{N}, 84^{\circ} 17^{\prime} \mathrm{W}$ & Oak-hickory \\
\hline \multicolumn{6}{|c|}{ (b) Agriculture and grassland sites } \\
\hline \multicolumn{6}{|l|}{ Agriculture (TAg) } \\
\hline \multicolumn{6}{|l|}{$\mathrm{C}_{3}$-crops $\left(\mathrm{Tag}-\mathrm{C}_{3}\right)$} \\
\hline Bondville ${ }^{\mathrm{b}}$ & IL/USA & 1998,2000 & Bvsoybean & $40^{\circ} 0^{\prime} \mathrm{N}, 88^{\circ} 18^{\prime} \mathrm{W}$ & Soybean \\
\hline Ponca $^{\mathrm{b}}$ & OK/USA & $\begin{array}{l}\text { August 1996- } \\
\text { August } 1997\end{array}$ & $\mathrm{PO}$ & $36^{\circ} 45^{\prime} \mathrm{N}, 97^{\circ} 05^{\prime} \mathrm{W}$ & Wheat \\
\hline Soroe $^{c}$ & Denmark & 1999 & Sowheat & $55^{\circ} 29^{\prime} \mathrm{N}, 11^{\circ} 39^{\prime} \mathrm{E}$ & Wheat \\
\hline \multicolumn{6}{|l|}{$\mathrm{C}_{4}$-crops $\left(\mathrm{Tag}-\mathrm{C}_{4}\right)$} \\
\hline Bondville ${ }^{\mathrm{b}}$ & IL/USA & 1997, 1999 & Bvcorn & $40^{\circ} 0^{\prime} \mathrm{N}, 88^{\circ} 18^{\prime} \mathrm{W}$ & Corn \\
\hline \multicolumn{6}{|l|}{ Grasslands } \\
\hline \multicolumn{6}{|c|}{ Boreal grasslands/tundra (BGr) } \\
\hline Happy Valley ${ }^{\mathrm{b}}$ & AK/USA & 1994-1995 & HA & $69^{\circ} 08^{\prime} \mathrm{N}, 148^{\circ} 50^{\prime} \mathrm{W}$ & $\begin{array}{l}\text { Eriophorum, Betula, } \\
\text { Ledum, Vaccinium, } \\
\text { Carex, Salix }\end{array}$ \\
\hline Atqasuk $^{b}$ & AK/USA & 1999 & AT & $70^{\circ} 29^{\prime} \mathrm{N}, 157^{\circ} 25^{\prime} \mathrm{W}$ & Eriophorum, Sedges \\
\hline Barrow $^{b}$ & AK/USA & 1998-1999 & BA & $70^{\circ} 18^{\prime} \mathrm{N}, 156^{\circ} 38^{\prime} \mathrm{W}$ & $\begin{array}{l}\text { Carex, Dupontia, } \\
\text { Arctophila }\end{array}$ \\
\hline Upad $^{\text {b }}$ & AK/USA & 1994 & UP & $70^{\circ} 16^{\prime} \mathrm{N}, 148^{\circ} 53^{\prime} \mathrm{W}$ & Eriophorum, Carex \\
\hline \multicolumn{6}{|c|}{ Temperate grasslands $\left(\mathrm{TGr}-\mathrm{C}_{3}\right)$} \\
\hline Little Washita ${ }^{\mathrm{b}}$ & OK/USA & 1997-1998 & $\mathrm{LW}$ & $34^{\circ} 58^{\prime} \mathrm{N}, 97^{\circ} 59^{\prime} \mathrm{W}$ & Rangeland \\
\hline Risoe $^{c}$ & Denmark & 1999 & RI & $55^{\circ} 29^{\prime} \mathrm{N}, 11^{\circ} 39^{\prime} \mathrm{E}$ & Meadow \\
\hline \multicolumn{6}{|c|}{ Temperate grasslands $\left(\mathrm{TGr}-\mathrm{C}_{4}\right)$} \\
\hline Shidler ${ }^{b}$ & OK/USA & $\begin{array}{l}\text { September 1996- } \\
\text { September } 1997\end{array}$ & $\mathrm{SH}$ & $36^{\circ} 51^{\prime} \mathrm{N}, 96^{\circ} 41^{\prime} \mathrm{W}$ & Tallgrass prairie \\
\hline
\end{tabular}

${ }^{\text {a }}$ Sites are sorted into functional vegetation types and within these groups by climate zone.

${ }^{\mathrm{b}}$ AmeriFlux project.

${ }^{\mathrm{c}}$ EUROFLUX project.

varied between 0.1 and 1.3 (winter) and 0.5 and 2.5 (summer) $\mathrm{g} \mathrm{C} \mathrm{m}^{-2}$ per day. Applying a bin-average over 15 days (see Eq. (1)) the error of daily $F_{\mathrm{NEE}}$, uptake or release estimates will be reduced by a factor of $1 / \sqrt{N}=1 / \sqrt{15}$ or 0.258 , resulting in errors for the mean of a 15-day period ranging from 0.04 to $0.65 \mathrm{~g} \mathrm{C} \mathrm{m}^{-2}$ per day. These estimations assumed that the measurements do not suffer from systematic errors, e.g., under-reading of nighttime fluxes. For more information on these assessments see Moncrieff et al. (1996, Eqs. (8) and (9)).

\section{Results}

Typical seasonal $\mathrm{CO}_{2}$ uptake of two examples of temperate forests is apparent in Fig. 2a. $\mathrm{CO}_{2}$ uptake of the coniferous and deciduous forests peak in June-July, but the coniferous forest shows some, yet low, photosynthetic activity during the winter months. In Fig. 2b, the yearlong uptake activity of the Mediterranean evergreen forest contrasts with the very short uptake period of a boreal coniferous site. Yet, maximum uptake rates are comparable especially in the months of May and August. In May, the long daytime period at $64^{\circ} \mathrm{N}$ becomes important and allows for an almost $4 \mathrm{~h}$ longer uptake period during the day. Larger differences can be observed in the nighttime fluxes, with the boreal system showing the lowest fluxes.

The seasonal development of $F_{\max }$ (maximum $\mathrm{CO}_{2}$ release during night), $F_{\min }$ (maximum $\mathrm{CO}_{2}$ uptake during the day), and $F_{\text {mean }}$ (daily mean $\mathrm{CO}_{2}$ flux) is shown as 30-day averages in Fig. 3. Data for all available years of each site were averaged to circum- 


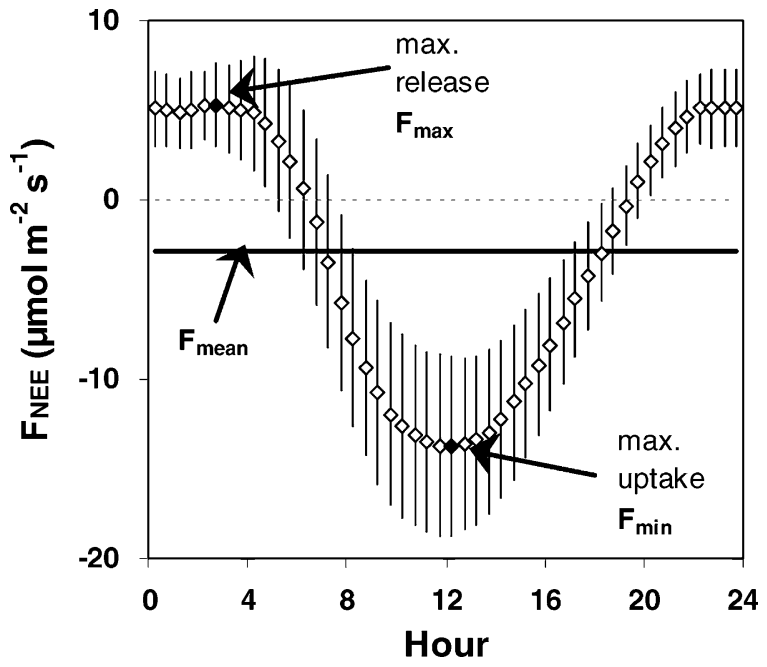

Fig. 1. Schematic view of a half-hourly binned diurnal course of $F_{\mathrm{NEE}}$ (net ecosystem $\mathrm{CO}_{2}$ exchange), and points of maximum $\mathrm{CO}_{2}$ release during night $\left(F_{\max }\right)$, maximum $\mathrm{CO}_{2}$ uptake during the day $\left(F_{\min }\right)$, and the overall mean of the period $\left(F_{\text {mean }}\right)$. Vertical bars indicate standard deviations of the means.

vent longer periods of gaps in the data and depict biome-specific patterns rather than inter-annual variability. The sites are sorted by climate zone (tropical to boreal from bottom to top) and vegetation type (evergreen forests, broadleaf deciduous forests, agriculture, and grasslands from left to right). In the following, we use BEC, cTEC, TEC, and wTEC for boreal, cold temperate, temperate and warm temperate evergreen conifers, $\mathrm{ME}$ and $\mathrm{TrE}$ for Mediterranean and tropical evergreen forests, BBD, cTBD, TBD, and wTBD for boreal, cold temperate, temperate and warm temperate broad-leaved deciduous forests, TAg for temperate agriculture, and $\mathrm{BGr}$ and $\mathrm{TGr}$ for boreal and temperate grasslands. The figure captures several typical findings for seasonal $\mathrm{CO}_{2}$ uptake and release rates of forest ecosystems: the long or year-round active period for temperate coniferous and evergreen broad-leaved forests, the very confined season length for deciduous and boreal forests, the similarity of maximum uptake rates in early season for different systems, and finally (with the exemption of boreal conifers) the compensatory behavior of $\mathrm{CO}_{2}$ uptake and release, high uptakes corresponding with high releases and low uptake with low releases. Highest and lowest $F_{\max }$ and $F_{\min }$ observed during the year and the corresponding day of the year are tabulated in Table 3. On average, and in agreement with leaf level studies, coniferous forests show lower maximum uptake than deciduous forests (see Table 3 with the exemption of Tharandt). For example, Reich et al. (1997) determined from a review of the literature, that potential photosynthesis and leaf respiration increase in similar proportion with decreasing leaf life-span, increasing leaf nitrogen, and increasing specific leaf area. This "functional convergence" makes sense in that short lived foliage (e.g., deciduous forests) have a relatively short season to gain carbon for growth and maintenance over the year, compared with coniferous forests that carry multiple years of foliage.

The typical seasonal behavior of $\mathrm{CO}_{2}$ uptake and release is reflected in the seasonal development of radiation $\left(Q_{\mathrm{P}}\right)$ and temperature $\left(T_{\mathrm{a}}\right)$ for differing biomes (Fig. 4). Absolute minimum and maximum values are reported in Table 2. In temperate and Mediterranean zones the seasonal development $Q_{\mathrm{P}}$ is very similar, however temperature regimes differ. Average pattern at high latitudes show $Q_{\mathrm{P}}$ of almost zero during arctic winter, and the extremes in $T_{\mathrm{a}}$ causing even evergreen forests to stop their assimilatory activity. Low variation of light and temperature in tropical zones makes it more likely that seasonal variability of carbon fluxes is due to moisture effects.

In Fig. 5, site specific absolute findings of $F_{\min }$ and $F_{\text {max }}$ from Fig. 3 are normalized to investigate the typical seasonal course for sites sorted by climate zone and vegetation type. Comparing the seasonal course of $F_{\text {min }}$ of temperate and boreal forest ecosystems, cTBD and BBD show the shortest, TBD and BEC intermediate, and TEC longest periods of activity. That is, in terms of seasonality of maximum uptake potential, TBD and BEC build one functional group. However, even though TBD and BEC showed similar phasing of $F_{\min }$, the pattern in $F_{\max }$ deviates largely with a very confined peak period in $\mathrm{BEC}$, and an almost year-round activity in the temperate systems. Contrarily, the patterns of $F_{\max }$ in TBD and TEC are much more alike than the respective seasonal course of $F_{\min }$. The same can be observed for $F_{\max }$ and $F_{\min }$ of BBD and BEC. Thus, $F_{\min }$ pattern of temperate (or boreal) forests seem to reflect the life-form (broad-leaved deciduous vs evergreen conifers), whereas $F_{\max }$ pattern appear to be determined by the climate zone.

The group cTEC contains a sub-alpine coniferous site with a short season (Niwot Ridge NR), that shows 


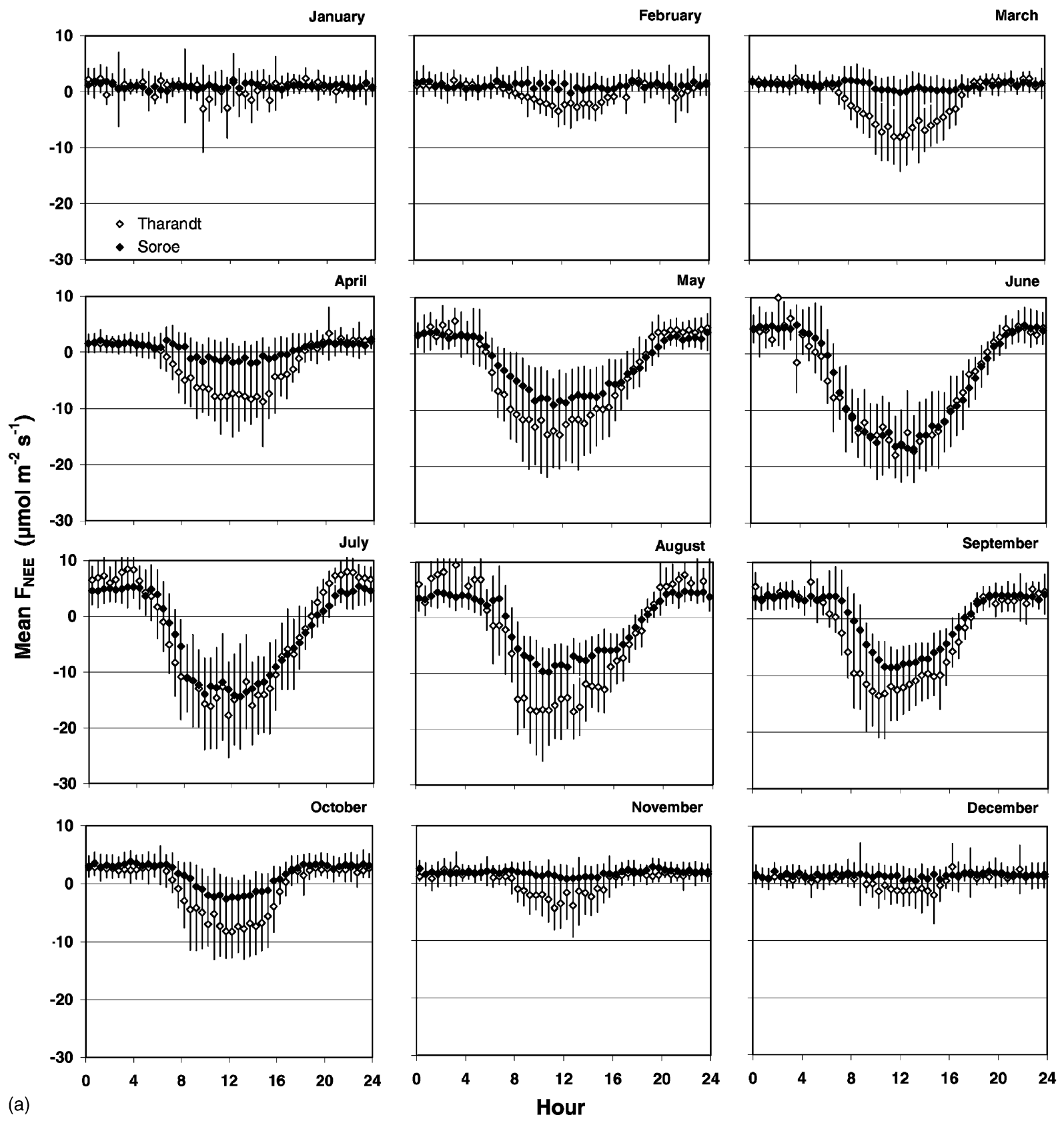

Fig. 2. Half-hourly binned diurnal courses of $F_{\mathrm{NEE}}$ (net ecosystem $\mathrm{CO}_{2}$ exchange) for each month of the year 1997 for two temperate forests. (a) Tharandt, a temperate coniferous site: open symbol; Soroe, a temperate deciduous site: closed symbol, and a Mediterranean and a boreal forest. (b) Castelporziano, a Mediterranean macchia: open symbol; Flakaliden, a boreal coniferous forest: closed symbol. Vertical bars indicate standard deviations of the means. 


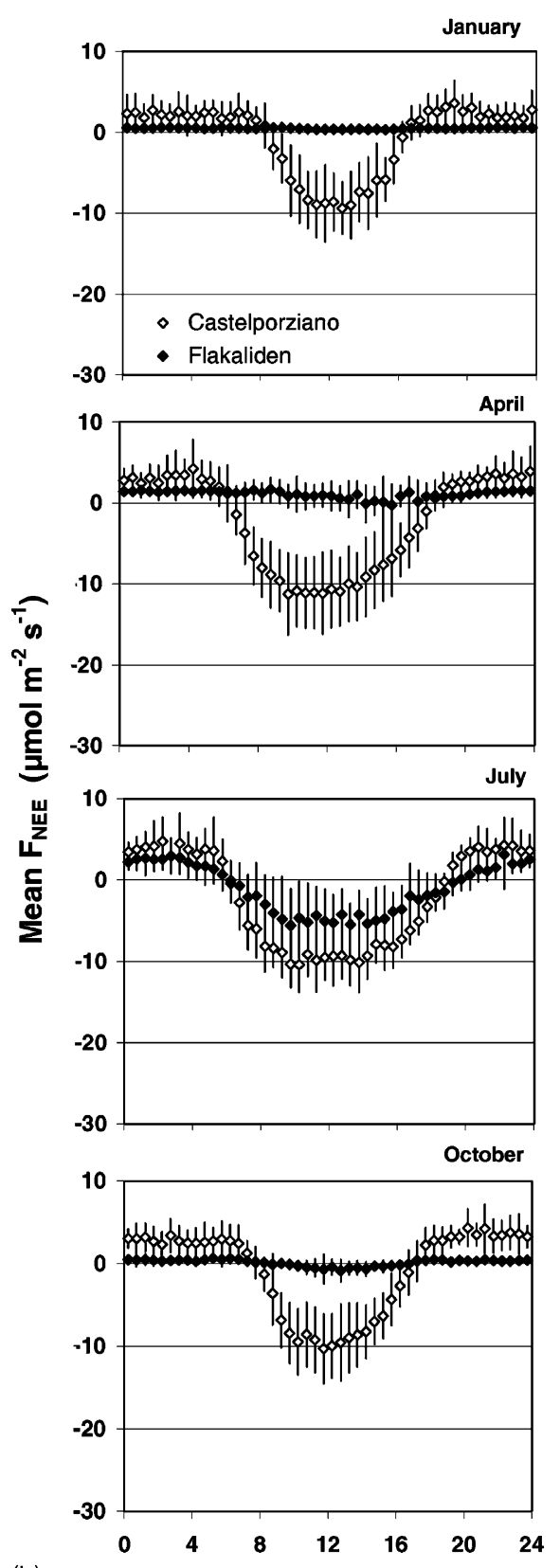

(b)
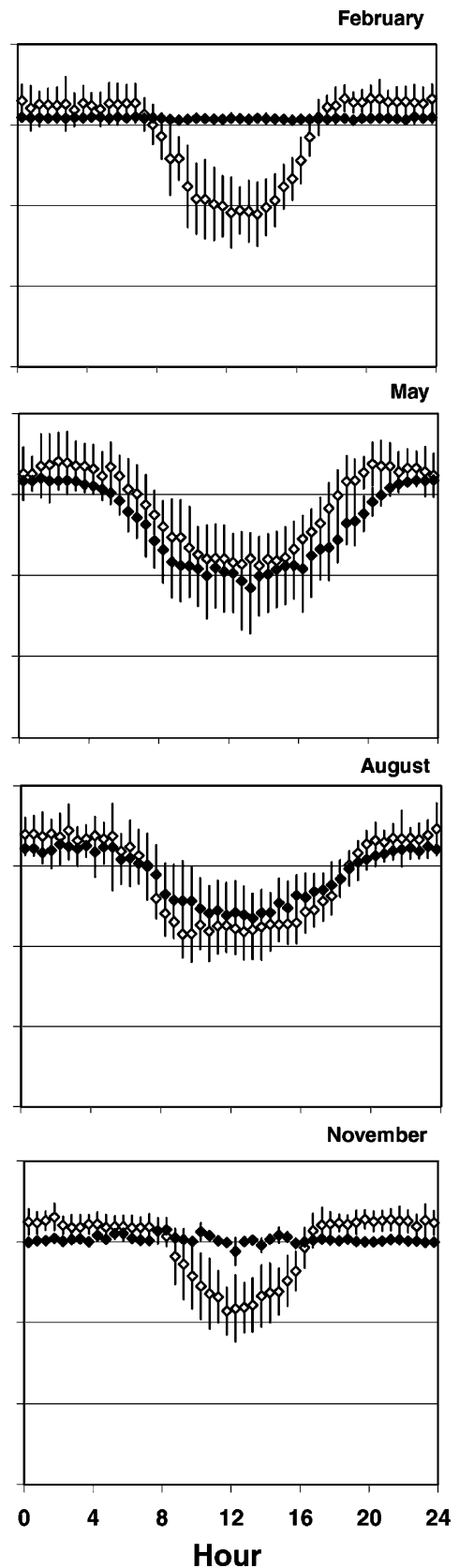

Fig. 2. (Continued).
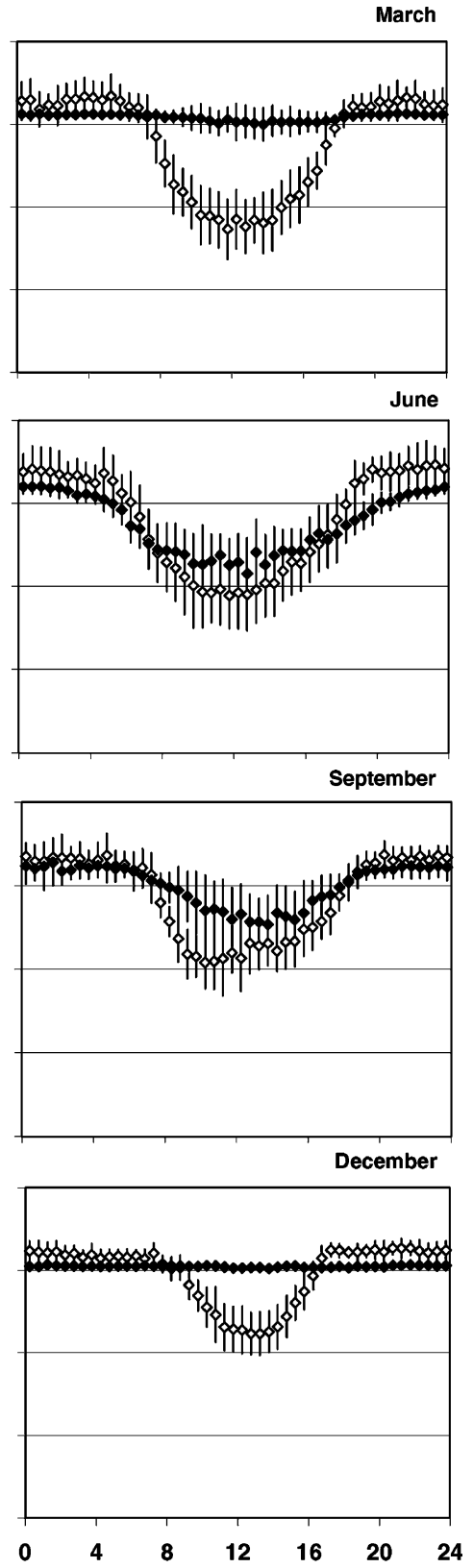

a high seasonal amplitude of $F_{\max }$. This pattern corresponds well with the observed $F_{\min }$ potential. The site Vielsalm (VI), a mixed deciduous-coniferous temperate forest (see Table 1a), obviously shows uptake potential in winter. The low uptake potential in spring and early summer for the TEC-site Brasschaat (BR) is probably an artefact due to footprint heterogeneity (residential areas and other anthropogenic influences). 


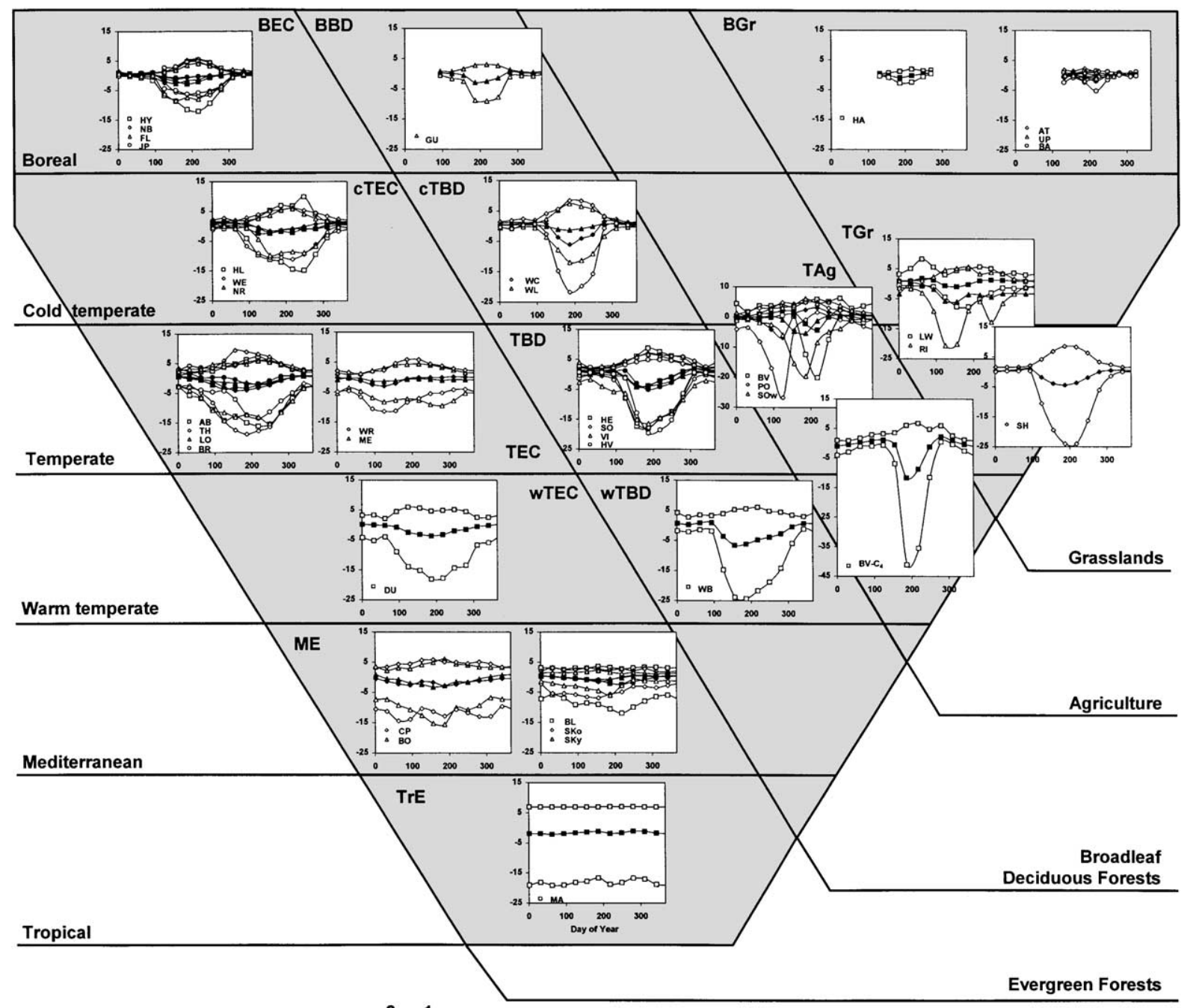

\section{$F_{\text {max }}, F_{\text {mean }}$, and $F_{\min }\left(\mu \mathrm{mol} \mathrm{m}^{-2} \mathrm{~s}^{-1}\right)$}

Fig. 3. Seasonal development of maximum $\mathrm{CO}_{2}$ release during night ( $F_{\max }$, shaded symbols), maximum $\mathrm{CO}_{2}$ uptake during the day $\left(F_{\min }\right.$, open symbols), and the overall mean of the period ( $F_{\text {mean }}$, closed symbols) for the sites listed in Table $1 \mathrm{a}$ and $\mathrm{b}$.

In TEC drought stressed temperate conifers (Metolius ME, Wind River WR) built a separate group, showing stress symptoms in their uptake potentials $F_{\min }$. The patterns in $F_{\text {max }}$ observed for those sites, however, do not seem to differ largely from those found for other temperate conifers, indicating that environmental stress affected photosynthesis more than respiration in those systems.

With the exemption of drought stressed systems, the seasonal amplitude of $F_{\max }$ for TEC typically matches the respective pattern of $F_{\min }$. For evergreen forests in maritime and Mediterranean climates (ME, including Californian chaparral) and a rainforest a year-round activity in $F_{\min }$ and $F_{\max }$ is clearly visible. The seasonal amplitude of $F_{\min }$ typically matches the respective pattern of $F_{\max }$, as it was seen for TEC. However, in contrast to drought stressed TEC, where $F_{\text {min }}$ was more affected than $F_{\max }$, there is some indication that drought can affect both, $F_{\min }$ and $F_{\max }$ (CP, SKy). 

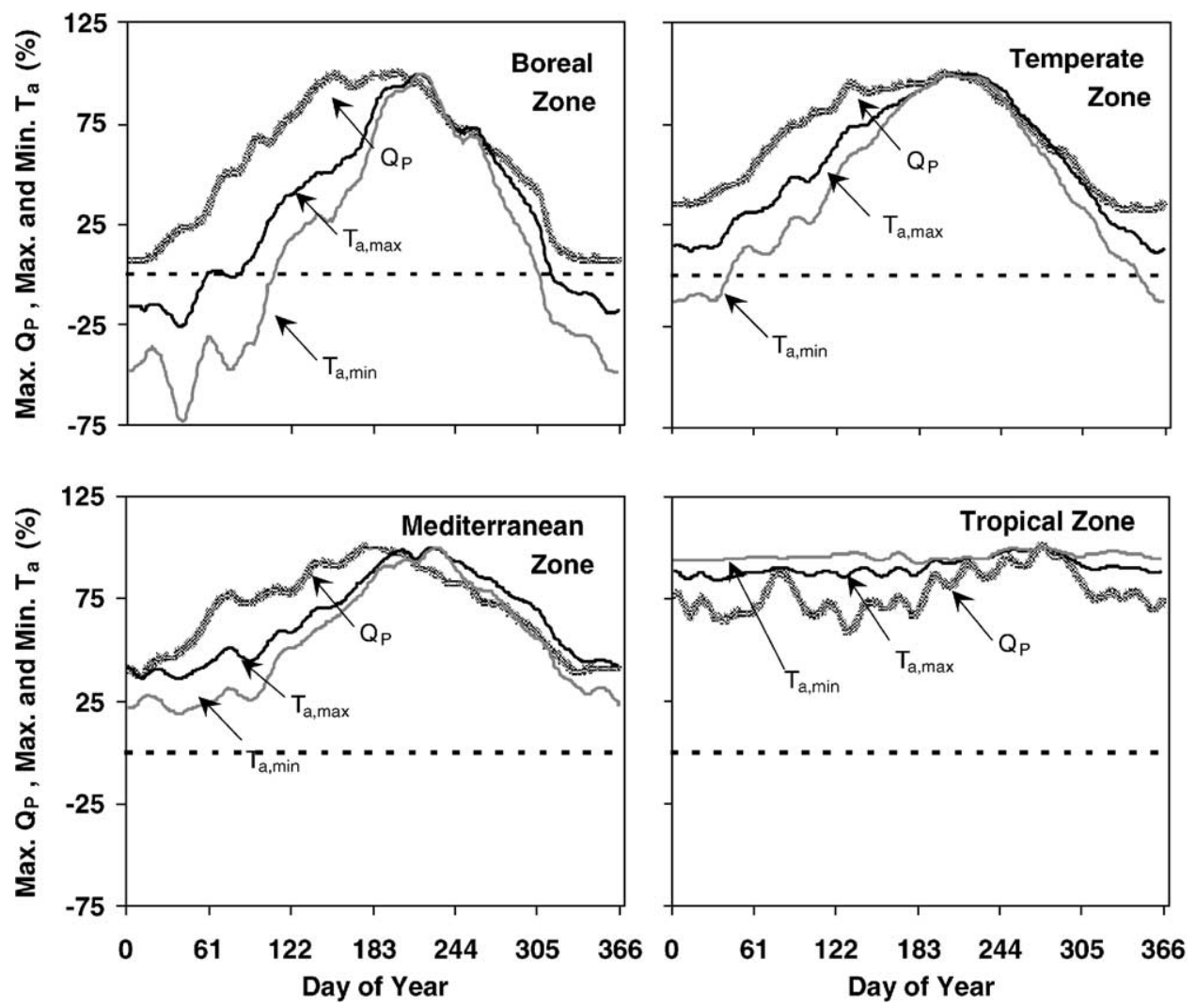

Fig. 4. Seasonal development of maximum diurnal radiation $\left(Q_{\mathrm{P}}\right)$, minimum and maximum diurnal air temperature $\left(T_{\mathrm{a}}\right)$ averaged for all sites of each zone (boreal $n=9$, temperate $n=24$, Mediterranean $n=5$, and tropical $n=1$ ). Data are normalized such that the maximum observed value equals $100 \%$. Negative values for temperature data indicate temperatures below $0{ }^{\circ} \mathrm{C}$.

The groups TAg, BGr, and TGr summarize the typical seasonal course of $F_{\min }$ of non-forested systems: managed and native grasslands, tundra, and $\mathrm{C}_{3}$ and $\mathrm{C}_{4}$ crops. The pattern for TGr is similar to TBD, but much shorter periods of activity are observed for TAg and BGr, as well as management effects of mowing (RI). Whereas the pattern observed in native and managed TGr (SH, RI) and BGr in $F_{\max }$ seem to follow their

Table 2

Maximum diurnal global radiation $\left(Q_{\mathrm{P}}\right)$, maximum and minimum diurnal air temperature $\left(T_{\mathrm{a}, \max }, T_{\mathrm{a}, \min }\right)$ together with the day of the year, where the seasonal maximum or minimum rates occur ${ }^{\mathrm{a}}$

\begin{tabular}{|c|c|c|c|c|c|c|}
\hline \multirow[t]{2}{*}{ Zone } & \multicolumn{2}{|l|}{$Q_{\mathrm{P}}$} & \multicolumn{2}{|l|}{$T_{\mathrm{a}, \max }$} & \multicolumn{2}{|l|}{$T_{\mathrm{a}, \min }$} \\
\hline & $\begin{array}{l}\text { Maximum, } \mathrm{W} \mathrm{m}^{-2} \\
\text { (day of year) }\end{array}$ & $\begin{array}{l}\text { Minimum, } \mathrm{W} \mathrm{m}^{-2} \\
\text { (day of year) }\end{array}$ & $\begin{array}{l}\text { Maximum, }{ }^{\circ} \mathrm{C} \\
\text { (day of year) }\end{array}$ & $\begin{array}{l}\text { Minimum, }{ }^{\circ} \mathrm{C} \\
\text { (day of year) }\end{array}$ & $\begin{array}{l}\text { Maximum, }{ }^{\circ} \mathrm{C} \\
\text { (day of year) }\end{array}$ & $\begin{array}{l}\text { Minimum, }{ }^{\circ} \mathrm{C} \\
\text { (day of year) }\end{array}$ \\
\hline Boreal & 524 (199) & $36(6)$ & $17.8(215)$ & $-4.6(39)$ & $10.2(217)$ & $-7.4(40)$ \\
\hline Temperate & $671(205)$ & 223 (336) & $24.5(206)$ & $2.8(359)$ & 16.1 (205) & $-2.1(1)$ \\
\hline Mediterranean & 771 (177) & $290(11)$ & $28.6(227)$ & $10.3(39)$ & $15.4(231)$ & $3.3(39)$ \\
\hline Tropical & $791(275)$ & $466(131)$ & $31.4(275)$ & $26.5(36)$ & $23.6(278)$ & 21.7 (184) \\
\hline
\end{tabular}

${ }^{\mathrm{a}}$ Data are averaged for available sites and years (see Table 1a and b) in four climatic zones, boreal, temperate, Mediterranean and tropical. 


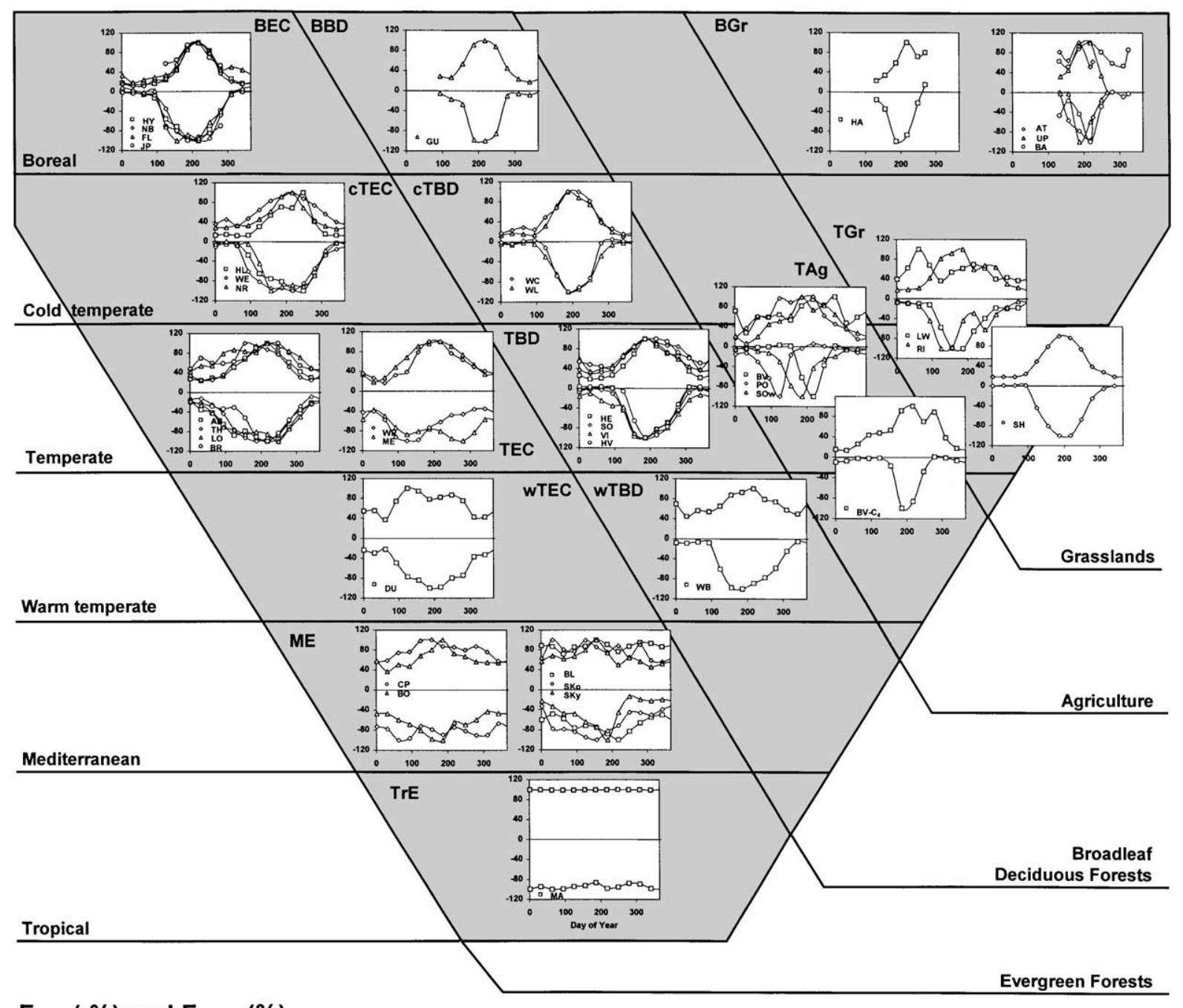

\section{$F_{\min }(-\%)$ and $F_{\max }(\%)$}

Fig. 5. Seasonal development of maximum $\mathrm{CO}_{2}$ release during night ( $F_{\max }$, shaded symbols), and maximum $\mathrm{CO}_{2}$ uptake during the day ( $F_{\min }$, open symbols) for the sites listed in Table 1a and b. Rates of $F_{\max }$ and $F_{\min }$ are given in percent of the respective maximum of the season, percentages for $F_{\min }$ are multiplied by -1 for more clarity in the graphs.

$F_{\min }$ pattern (Fig. 5 right panels), observed $F_{\max }$ in the rangeland (LW) and TAg do not correspond to the respective $F_{\min }$. Maximum uptake periods are strongly confined to the phenological cycle of crops, whereas maximum release of $\mathrm{CO}_{2}$ seems to change amplitude and phase the entire year, eventually due to field management practice.

To summarize the panels of Fig. 5, the average seasonal amplitude of $F_{\max }$ and $F_{\min }$ for different vegetation functional groups are compared in Fig. 6. On a scale from 0 (zero $F_{\min }$ or $F_{\max }$ ), to 100 (maximum $F_{\min }$ or $F_{\max }$ ), seasonal values of $F_{\min }$ in the TrE system ranged from 70 to 100 , seasonal values of $F_{\max }$ from 98 to 100 . In ME, $F_{\min }$ varied seasonally between 27 (during summer drought) and 100, $F_{\max }$ ranged between 32 and 100. Both, BEC and deciduous forests show $F_{\min }$ values less than zero in winter (source of $\mathrm{CO}_{2}$ ). One could say, BEC are "function- 


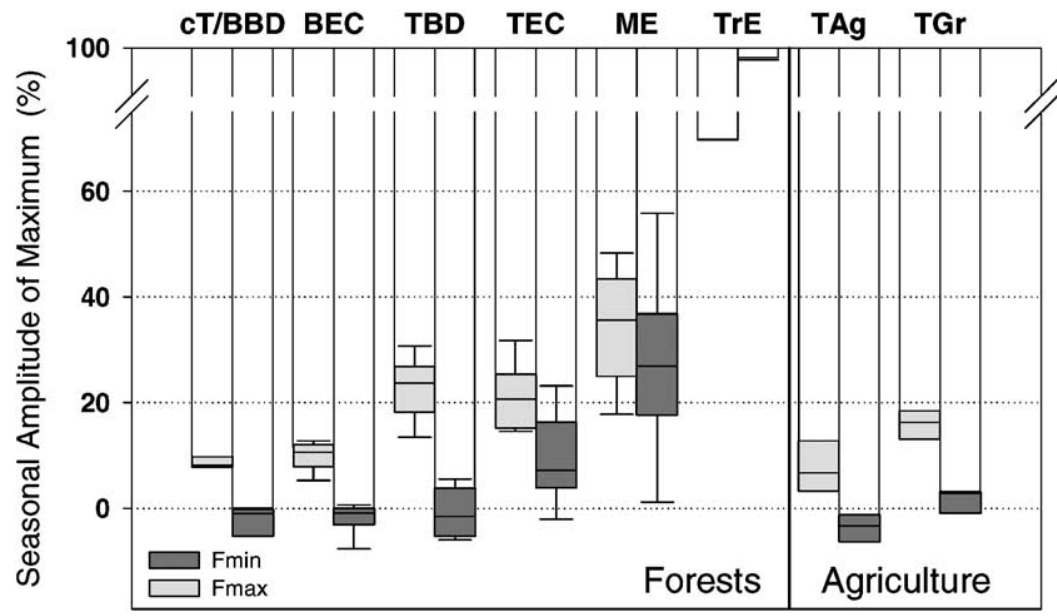

Fig. 6. Seasonal amplitudes of maximum $\mathrm{CO}_{2}$ release $\left(F_{\max }\right)$ and uptake $\left(F_{\min }\right)$ grouped by functional type (cT/BBD: cold temperate and boreal broadleaf deciduous, BEC: boreal evergreen conifers, TBD: temperate broadleaf deciduous, TEC: temperate evergreen conifers, ME: Mediterranean forests, TrE: rainforest, TAg: temperate crops, TGr: temperate grasslands). Data are derived calculating the ratio (\%) between minimum and maximum values of uptake (or release) reported in Table 3. Box charts are used to emphasize total range, and median.

ally deciduous" in terms of seasonal pattern of both, $F_{\min }$ and the ratio between daytime and nighttime net $\mathrm{CO}_{2}$ uptake $\left(F_{\text {day }} / F_{\text {night }}\right.$ see below, Fig. 7$)$. However, they differ in the range of seasonal $F_{\max }$. BEC usually show seasonal reductions from 100 to $10 \%$, similar to cT/BBD with reductions to $9 \%$. TBD reduce $F_{\max }$ to only $23 \%$, forming a group with TEC (reductions to $22 \%$ ). Overall, the patterns seem relatively stable for these functional groups. The seasonal amplitude of $F_{\min }$ of managed TGr and TAg shows reductions to zero, much in contrast to the reducing of $F_{\max }$, which resembles more the patterns observed in temperate forests (average reduction to 12 on a scale from 0 to 100). For BGr, measurements were only available for short periods during the growing season, so reduction rates were not evaluated.

So far, we were analysing phasing and amplitude of net carbon exchange, that is seasonal timing, and diurnal capacities of carbon fluxes in ecosystems. For information on net carbon sequestration of ecosystems, and the relative importance of daytime and nighttime fluxes, integral fluxes have to be compared (Fig. 7). Among the coniferous forests (BEC, TEC), the sites Aberfeldy and Tharandt $(\mathrm{AB}, \mathrm{TH})$ have the biggest net uptake of carbon ( $F_{\text {total}}$, upper panels Fig. 7) at each time of the year while North Boreas (NB) has the smallest. Day and nighttime integrals at $\mathrm{NB}$ almost compensate each other, whereas in $\mathrm{AB}$ and $\mathrm{TH}$ the daytime integral is much higher than the nighttime. Several factors contribute to those integral fluxes - day length and photosynthetic capacity, but also the dependence of photosynthetic and respiratory processes on environmental conditions (light, temperature, soil moisture, etc.). In general, nighttime integral ecosystem $\mathrm{CO}_{2}$ release $\left(F_{\text {night }}\right.$, middle panels Fig. 7) in boreal forests (BEC, BBD) was smaller than in temperate forests (TEC, TBD). However, in the beginning of the growing season of boreal systems, $F_{\text {night }}$ was much smaller than daytime uptake $\left(F_{\text {day }}\right)$, resulting in abrupt changes in the ratio between $F_{\text {day }}$ and $F_{\text {night }}$ (lower panels Fig. 7). This ratio is much more conservative for temperate, especially temperate coniferous forests (TEC). In boreal forests, the changes are a result of shorter nighttime periods, but eventually indicate an effect of low spring temperatures, that delay soil microbial processes.

\section{Discussion}

In this study we presented phasing and amplitude of net ecosystem exchange of carbon dioxide $\left(F_{\mathrm{NEE}}\right)$ over the course of the year. Data were obtained from eddy covariance tower networks from a variety of 

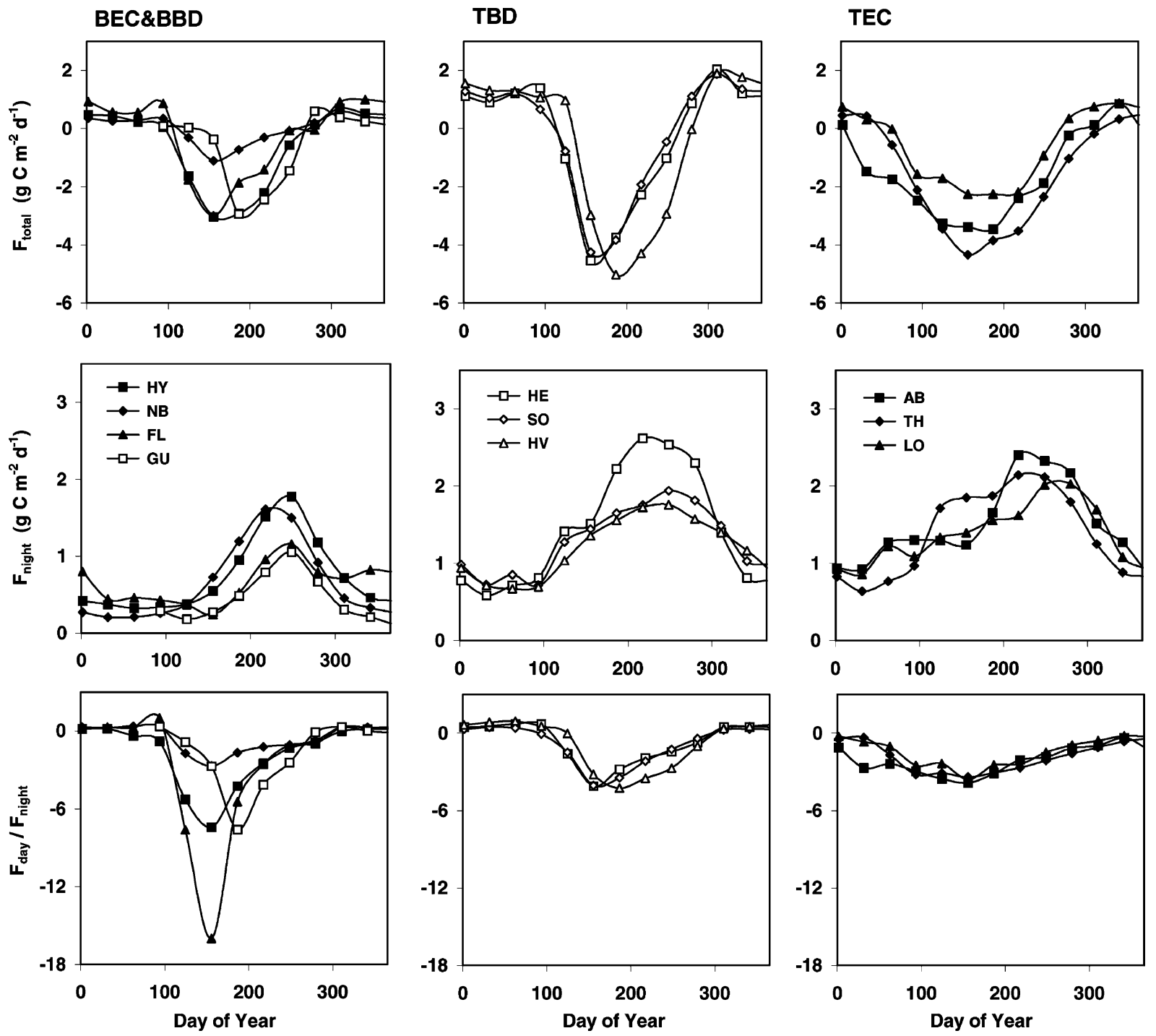

Fig. 7. Seasonal development of total carbon uptake $\left(F_{\text {total }}\right.$, upper panel), integral carbon release during night $\left(F_{\text {night }}\right.$, middle panel), and integral carbon uptake during the daytime $\left(F_{\text {day }}\right.$, lower panel, all in $\left.\mathrm{g} \mathrm{C} \mathrm{m}^{-2} \mathrm{~d}^{-1}\right)$ for the sites listed in Table $1 \mathrm{a}$,b.

ecosystems of the Northern Hemisphere. We derived seasonal patterns of daytime and nighttime fluxes to evaluate concepts of functional vegetation types in terms of their differences in respiratory and net ecosystem $\mathrm{CO}_{2}$ exchange potentials.

Several studies exist, that compare eddy covariance data and modeled ecosystem fluxes (e.g., Aber et al., 1995; Kimball et al., 1997; Law et al., 2000, 2001; Kellomäki and Wang, 2000; Williams et al., 2000;
Baldocchi and Wilson, 2001; Falge et al., 2001a; Wilson et al., 2001). Those studies form a crucial link between flux estimates on plot and landscape scale (Running et al., 1999). Overall these efforts were quite successful, however problems in model performance were identified in terms of nighttime or respiration fluxes, rainy days, site heterogeneity (species, terrain), drought effects, maximum uptake potential, and phenology. Whereas low turbulence during night 
and rain affect the performance of the eddy covariance system and subsequently the data quality (for an overview see Baldocchi et al., 2000; Aubinet et al., 2000), shortcomings due to site heterogeneity, drought effects, and phenology require improved modeling tools. Seasonal maximum and minimum fluxes were derived for use in model applications (parameterization, validation), generalizations of seasonal patterns of ecosystem fluxes were analyzed to help improving phenology modules.

When normalized to the respective maximum values, typical annual dynamics of maximum daytime uptake, and nighttime release could be observed for each of the major forest types, boreal and temperate coniferous (BEC, TEC), boreal and temperate deciduous forests (BBD, TBD), Mediterranean evergreen (ME), and rainforest (TrE), native and managed temperate grasslands (TGr), tundra (BGr), and $\mathrm{C}_{3}$ and $\mathrm{C}_{4}$ crops (TAg). Within each group, the length of the season decreased from southern to northern sites (in the Northern Hemisphere), however the phasing of respiratory and assimilatory processes differed within the functional types. Whereas for TEC maximum $\mathrm{CO}_{2}$ uptake and maximum nighttime release are in phase and show similar normalized amplitudes (Fig. 5), the phases of maximum uptake and release in TBD and BEC are shifted (Figs. 3 and 5). Owing to low spring temperatures in BEC, nighttime ecosystem respiration was delayed compared to daytime uptake in the beginning of the growing season (Fig. 7), contradicting, e.g., the results from Peylin et al. (1999). Analyzing the high latitude $\delta^{18} \mathrm{O}$ seasonal cycle together with a general atmospheric circulation model they found, that the relative contributions of photosynthesis and respiration to the overall seasonal cycle are similar. For BEC however, the lag between respiration and assimilation results in the highest net fluxes in the early season. Similarly, assimilatory processes in TBD start to peak before respiration reaches its maximum (e.g., Wilson et al., 2000). In terms of the seasonal development of maximum daytime uptake, TBD, BEC and cold temperate (high altitude) conifers and TGr form one functional class, and TEC another. BGr and TAg show a similar seasonal pattern, as do ME or TrE. In contrast, the seasonality of maximum nighttime release of $\mathrm{CO}_{2}$ by TBD matches the patterns of TEC rather than that of boreal forests. Generalizations of such seasonal patterns in $\mathrm{CO}_{2}$ uptake and release potentials might help to overcome shortcomings in phenology modules of SVAT or terrestrial biogeochemical models (e.g., Craig et al., 1998; Heimann et al., 1998). They also might serve to identify new "functional" types of vegetation based on seasonal $\mathrm{CO}_{2}$ uptake and release patterns, for use in dynamic global vegetation models (e.g., Potter and Klooster, 1999; Kleidon and Mooney, 2000; Kucharik et al., 2000) or inversion studies.

Time delays in the seasonal phasing of nighttime respiration and net ecosystem exchange (daytime data) were observed for TBD and BEC. These periods where respiratory and assimilatory processes are unbalanced might make these systems more susceptible to changes in climatic conditions or management practices, as was shown for the dependence of sink-source strength of boreal forests on spring onset (Black et al., 2000; White et al., 1999). In addition, the fact that nighttime temperatures increase relatively more than daytime temperatures (Easterling et al., 1997) may cause a relative elongation of the respiratory phase compared to the assimilatory phase, affecting the vulnerability of ecosystems during periods where $\mathrm{CO}_{2}$ uptake and release are out of phase. Given the small differences in the seasonality of $\mathrm{CO}_{2}$ release and uptake, humid TEC seem more stable than boreal forests, TBD, or $\mathrm{TAg}$ and $\mathrm{TGr}$ in terms of the potential response of net ecosystem carbon fluxes to future climate conditions. In TAg and TGr, temporal variations in respiratory activity are highly irregular, and the seasonality of potential $\mathrm{CO}_{2}$ release of these systems could not be generalized.

Analyzing the seasonal phasing and amplitude of fluxes might lead to a more detailed classification of forested ecosystems. Seasonal amplitude of maximum $\mathrm{CO}_{2}$ uptake and release increases in the order $\operatorname{TrE}<\mathrm{ME}$ and TEC $<$ TBD, BBD and BEC. A striking result of this paper is that in terms of seasonal phasing, TEC and BEC fall in two different classes, a feature not entirely adopted by global modelers, even when they use maps of actual vegetation as input. Models based on Matthews vegetation types (Matthews, 1983), and their derivatives, place temperate and boreal coniferous forests into one class of "evergreen needle-leaf forest". Even global data sets, as the ISLSCP global land cover data set (International Satellite Land Surface Climatology Project, DeFries and Townshend, 1994), are modified to be consistent with $\mathrm{SiB}$ vegetation classes (Dorman and Sellers, 
Table 3

Maximum and minimum $\mathrm{CO}_{2}$ uptake (during daytime) and $\mathrm{CO}_{2}$ release (during nighttime) together with the day of the year, where maximum or minimum rates occur, for 39 sites from the EUROFLUX and AmeriFlux projects (data are averaged for available years)

\begin{tabular}{|c|c|c|c|c|c|}
\hline \multirow[t]{2}{*}{ Type $^{\mathrm{a}}$} & \multirow[t]{2}{*}{ Site } & \multicolumn{2}{|c|}{$F_{\min }\left(\right.$ maximum $\mathrm{CO}_{2}$ uptake during day) } & \multicolumn{2}{|c|}{$F_{\max }\left(\right.$ maximum $\mathrm{CO}_{2}$ release during night $)$} \\
\hline & & $\begin{array}{l}\text { Maximum, } \\
\mu \mathrm{mol} \mathrm{CO}_{2} \mathrm{~m}^{-2} \mathrm{~s}^{-1} \\
\text { (day of year) }\end{array}$ & $\begin{array}{l}\text { Minimum, } \\
\mu \text { mol } \mathrm{CO}_{2} \mathrm{~m}^{-2} \mathrm{~s}^{-1} \\
\text { (day of year) }\end{array}$ & $\begin{array}{l}\text { Maximum, } \\
\mu \text { mol } \mathrm{CO}_{2} \mathrm{~m}^{-2} \mathrm{~s}^{-1} \\
\text { (day of year) }\end{array}$ & $\begin{array}{l}\text { Minimum, } \\
\mu \mathrm{mol} \mathrm{CO}_{2} \mathrm{~m}^{-2} \mathrm{~s}^{-1} \\
\text { (day of year) }\end{array}$ \\
\hline \multicolumn{6}{|c|}{ Evergreen forests } \\
\hline $\mathrm{BEC}$ & $\begin{array}{l}\text { North Boreas } \\
\text { Flakaliden }^{\mathrm{c}} \\
\text { Norunda }^{\mathrm{c}} \\
\text { Hyytiala }^{\mathrm{c}}\end{array}$ & $\begin{array}{r}-7.4(239) \\
-11.2(143) \\
-22.4(191) \\
-12.8(219)\end{array}$ & $\begin{array}{l}0.0(310) \\
0.9(371) \\
0.2(7) \\
0.2(351)\end{array}$ & $\begin{array}{r}6.2(201) \\
4.6(211) \\
14.4(209) \\
5.9(210)\end{array}$ & $\begin{array}{l}0.5(54) \\
0.5(8) \\
1.8(44) \\
0.6(47)\end{array}$ \\
\hline cTEC & $\begin{array}{l}\text { Niwot Ridge } \\
\text { Howland }^{\mathrm{b}} \\
\text { Weidenbrunnen }^{\mathrm{c}}\end{array}$ & $\begin{array}{l}-10.4(150) \\
-16.8(244) \\
-11.8(232)\end{array}$ & $\begin{aligned}-0.1 & (334) \\
-0.1 & (14) \\
0.4 & (35)\end{aligned}$ & $\begin{aligned} & 6.7(220) \\
& 12.4(246) \\
& 6.8(225)\end{aligned}$ & $\begin{array}{l}1.4(331) \\
0.7(74) \\
1.6(66)\end{array}$ \\
\hline TEC & $\begin{array}{l}\text { Wind River }{ }^{\mathrm{b}} \\
\text { Aberfeldy }^{\mathrm{c}} \\
\text { Tharandt }^{\mathrm{c}} \\
\text { Loobos }^{\mathrm{c}} \\
\text { Brasschaat }^{\mathrm{c}} \\
\text { Metolius }^{\mathrm{b}}\end{array}$ & $\begin{array}{l}-12.7(132) \\
-17.3(216) \\
-20.1(175) \\
-19.6(246) \\
-15.8(202) \\
-10.5(316)\end{array}$ & $\begin{array}{l}-2.7(323) \\
-2.5(358) \\
-1.0(33) \\
-1.9(351) \\
-0.9(12) \\
-2.5(19)\end{array}$ & $\begin{array}{r}6.8(199) \\
8.0(225) \\
10.8(160) \\
6.6(139) \\
6.6(209) \\
4.7(190)\end{array}$ & $\begin{array}{l}1.4(356) \\
1.2(26) \\
1.6(35) \\
2.1(358) \\
2.1(310) \\
0.7(21)\end{array}$ \\
\hline wTEC & Duke Forest ${ }^{b}$ & $-21.3(191)$ & $-1.5(55)$ & $2.0(137)$ & $1.0(55)$ \\
\hline ME & $\begin{array}{l}\text { Castelporziano }^{\mathrm{c}} \\
\text { Bordeaux }^{\mathrm{c}} \\
\text { Blodgett Forest }^{\mathrm{b}} \\
\text { Sky Oaks young } \\
\text { Sky Oaks old }\end{array}$ & $\begin{array}{c}-16.2(66) \\
-17.4(186) \\
-12.3(225) \\
-6.4(184) \\
-7.4(79)\end{array}$ & $\begin{array}{l}-9.0(334) \\
-4.7(315) \\
-3.7(310) \\
-0.1(219) \\
-1.7(219)\end{array}$ & $\begin{array}{l}7.5(134) \\
6.8(184) \\
4.4(309) \\
2.8(162) \\
3.5(44)\end{array}$ & $\begin{array}{ll}2.7 & (346) \\
1.9 & (29) \\
2.1 & (143) \\
0.5 & (220) \\
1.5 & (247)\end{array}$ \\
\hline TrE & Manaus $^{b}$ & $-22.0(76)$ & $-15.3(189)$ & $7.0(325)$ & $7.0(115)$ \\
\hline $\begin{array}{l}\text { Deciduous } \\
\text { BBD }\end{array}$ & $\begin{array}{l}\text { ests } \\
\text { Gunnarsholt }\end{array}$ & $-11.2(232)$ & $0.1(300)$ & $3.6(233)$ & $0.3(346)$ \\
\hline cTBD & $\begin{array}{l}\text { Park Falls/WLEF } \\
\text { Willow Creek }\end{array}$ & $\begin{array}{l}-12.9(176) \\
-22.9(190)\end{array}$ & $\begin{array}{l}0.0(74) \\
1.5(292)\end{array}$ & $\begin{array}{r}7.8(169) \\
10.1(239)\end{array}$ & $\begin{array}{l}0.6(350) \\
1.0(353)\end{array}$ \\
\hline TBD & $\begin{array}{l}\text { Vielsalm }^{\mathrm{c}} \\
\text { Soroe }^{\mathrm{c}} \\
\text { Hesse }^{\mathrm{c}} \\
\text { Harvard }^{\mathrm{b}}\end{array}$ & $\begin{array}{l}-17.3(179) \\
-19.5(175) \\
-19.6(177) \\
-20.6(190)\end{array}$ & $\begin{aligned} &-1.0(21) \\
& 0.3(337) \\
& 1.2(315) \\
& 1.0(331)\end{aligned}$ & $\begin{array}{l}7.4(197) \\
8.1(189) \\
9.3(187) \\
5.4(196)\end{array}$ & $\begin{array}{l}1.5(40) \\
1.9(34) \\
1.3(33) \\
1.7(98)\end{array}$ \\
\hline wTBD & Walkerbranch $^{\mathrm{b}}$ & $-26.4(176)$ & $-0.9(332)$ & $7.2(209)$ & $1.8(39)$ \\
\hline $\begin{array}{c}\text { Agriculture } \\
\mathrm{TAg}^{-\mathrm{C}_{3}}\end{array}$ & $\begin{array}{l}\text { Bondville } \mathrm{C}_{3}{ }^{\mathrm{b}} \\
\text { Ponca }^{\mathrm{b}} \\
\text { Soroe }^{\mathrm{c}}\end{array}$ & $\begin{array}{l}-21.1(227) \\
-29.5(124) \\
-23.2(187)\end{array}$ & $\begin{array}{l}1.1(143) \\
2.2(221) \\
0.2(324)\end{array}$ & $\begin{array}{l}7.8(267) \\
6.2(190) \\
8.7(190)\end{array}$ & $\begin{array}{l}1.3(36) \\
0.6(342) \\
0.2(32)\end{array}$ \\
\hline $\mathrm{TAg}-\mathrm{C}_{4}$ & Bondville $\mathrm{C}_{4}{ }^{\mathrm{b}}$ & -47.7 (199) & $0.8(268)$ & 8.4 (206) & $0.3(51)$ \\
\hline $\begin{array}{l}\text { Grasslands } \\
\text { BGr }\end{array}$ & $\begin{array}{l}\text { Happy Valley } \\
\text { Atqasuk }^{\mathrm{b}} \\
\text { Barrow }^{\mathrm{b}} \\
\text { Upad }^{\mathrm{b}}\end{array}$ & $\begin{array}{l}-4.0(198) \\
-1.7(209) \\
-6.0(203) \\
-2.5(187)\end{array}$ & $\begin{array}{l}0.8(255) \\
0.8(210) \\
0.3(273) \\
0.0(161)\end{array}$ & $\begin{array}{l}2.2(218) \\
3.8(178) \\
2.5(174) \\
1.3(216)\end{array}$ & $\begin{array}{l}0.4(147) \\
0.7(194) \\
0.2(157) \\
0.3(237)\end{array}$ \\
\hline TGr- $\mathrm{C}_{3}$ & $\begin{array}{l}\text { Little Washita } \\
\text { Risoe }^{\mathrm{c}}\end{array}$ & $\begin{array}{r}-9.2(176) \\
-23.9(122)\end{array}$ & $\begin{array}{l}-0.3(356) \\
-0.7(336)\end{array}$ & $\begin{array}{l}9.1(66) \\
6.8(175)\end{array}$ & $\begin{array}{l}1.7(110) \\
0.8(361)\end{array}$ \\
\hline TGr- $\mathrm{C}_{4}$ & Shidler ${ }^{b}$ & $-26.5(206)$ & $0.6(74)$ & $9.5(209)$ & $1.5(7)$ \\
\hline
\end{tabular}

${ }^{\text {a }}$ For abbreviations see Table 1.

${ }^{\mathrm{b}}$ AmeriFlux project.

${ }^{c}$ EUROFLUX project. 
1989). Our results however indicate, that TEC and BEC should be viewed as separate classes, in terms of seasonal amplitude and phasing of: (a) net carbon fluxes, and (b) the relative contribution of respiratory to net ecosystem fluxes. A classification of coniferous (and deciduous) forests by climate zone (temperate, boreal, etc.) in global applications could also help to assimilate observed differences of these systems (e.g., annual $F_{\mathrm{NPP}}$, wood increment, carbon turnover time, or response to elevated $\mathrm{CO}_{2}$, Lloyd, 1999).

Maximum observed $\mathrm{CO}_{2}$ uptake values over the course of the year $\left(F_{\min }\right.$, Table 3$)$ are signatures for the potential carbon sequestration capacity of the ecosystem. Such maximum capacities are needed for ecosystem flux model parameterization and validation, e.g., for use in regional or global up-scaling schemes. Therefore, the generality of the results presented here was evaluated by means of differences in $F_{\min }$ as compared to a recent review study across ecosystem functional types (Buchmann and Schulze, 1999). $F_{\min }$, grouped and averaged by functional or biome type, were compared with maximum light saturated values (Asmax) from Buchmann and Schulze (1999) (data from micrometeorological techniques). Despite differences in derivation of the parameters, the range of maximum rates was similar in the review paper and our results (Fig. 8), showing maxima between
-48 and $-2 \mu \mathrm{mol} \mathrm{m}^{-2} \mathrm{~s}^{-1}$, decreasing in the order TAg-C $4>$ TAg-C $3>$ TBD $>$ TEC $>$ BEC $>$ BGr. In our data, only 1-3 data sets were available for $\mathrm{C}_{4}$ and $\mathrm{C}_{3}$-grassland, or tropical evergreen forest, thus derived average $F_{\min }$-values might not be representative for those functional types. Yet, the correspondence of the overall pattern across ecosystems is promising with respect to generalization of carbon sequestration capacities of ecosystem functional types.

Eddy covariance methods measure net ecosystem production $\left(F_{\mathrm{NEP}}\right)$, and allow for estimates of $S_{\mathrm{NEP}>0}$, the number of days per year where daily $F_{\mathrm{NEP}}$ is positive (Fig. 9). These estimates for season length integrate active periods of heterotrophic and autotrophic processes. For temperate coniferous and deciduous forests (TEC, TBD), the amount of annual $F_{\mathrm{NEP}}$ divided by leaf area index (LAI, left panel) or mean annual precipitation (MAP, right panel) increased with $S_{\mathrm{NEP}>0}$. However, comparing the two vegetation types, deciduous forests are more "effective", i.e., at a given length of the active period TBD have a higher $F_{\text {NEP }}$ than TEC. On average in TBD, only 120 days with positive $F_{\text {NEP }}$ are needed to change the carbon balance from a source to a sink, as compared to 147 days in TEC indicating the costs for maintaining evergreen foliage (see equations given in Fig. 9). With respect to $S_{\mathrm{NEP}>0}, F_{\mathrm{NEP}}$ per leaf area of the temperate

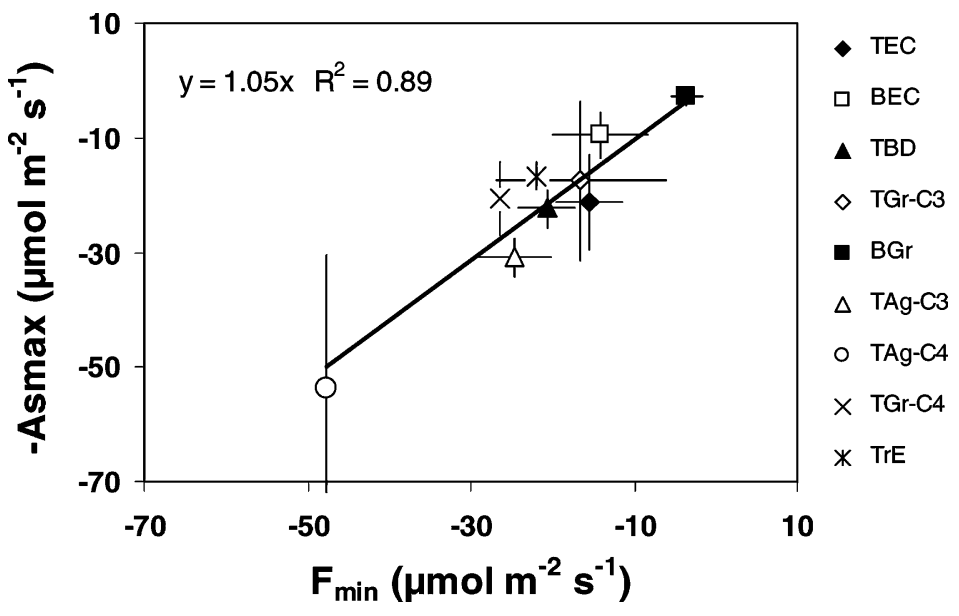

Fig. 8. Comparison between light saturated maximum values of net ecosystem exchange (Asmax, from Buchmann and Schulze, 1999), and the maximum $\mathrm{CO}_{2}$ uptake, derived as the seasonal optimum of maximum observations. Vertical bars indicate standard deviation of the mean of Asmax, horizontal bars the standard deviation of the seasonal maximum values for the respective functional class (TEC: temperate evergreen conifers, BEC: boreal evergreen conifers, TBD: temperate broadleaf deciduous, $\mathrm{TGr}_{3} \mathrm{C}_{3}$ : temperate $\mathrm{C}_{3}$ grasslands, $\mathrm{BGr}$ : tundra, TAg- $\mathrm{C}_{3}$ : temperate $\mathrm{C}_{3}$ crops, TAg- $\mathrm{C}_{4}$ : temperate $\mathrm{C}_{4}$ crops, TGr- $\mathrm{C}_{4}$ : temperate $\mathrm{C}_{4}$ grasslands, TrE: rainforest). 

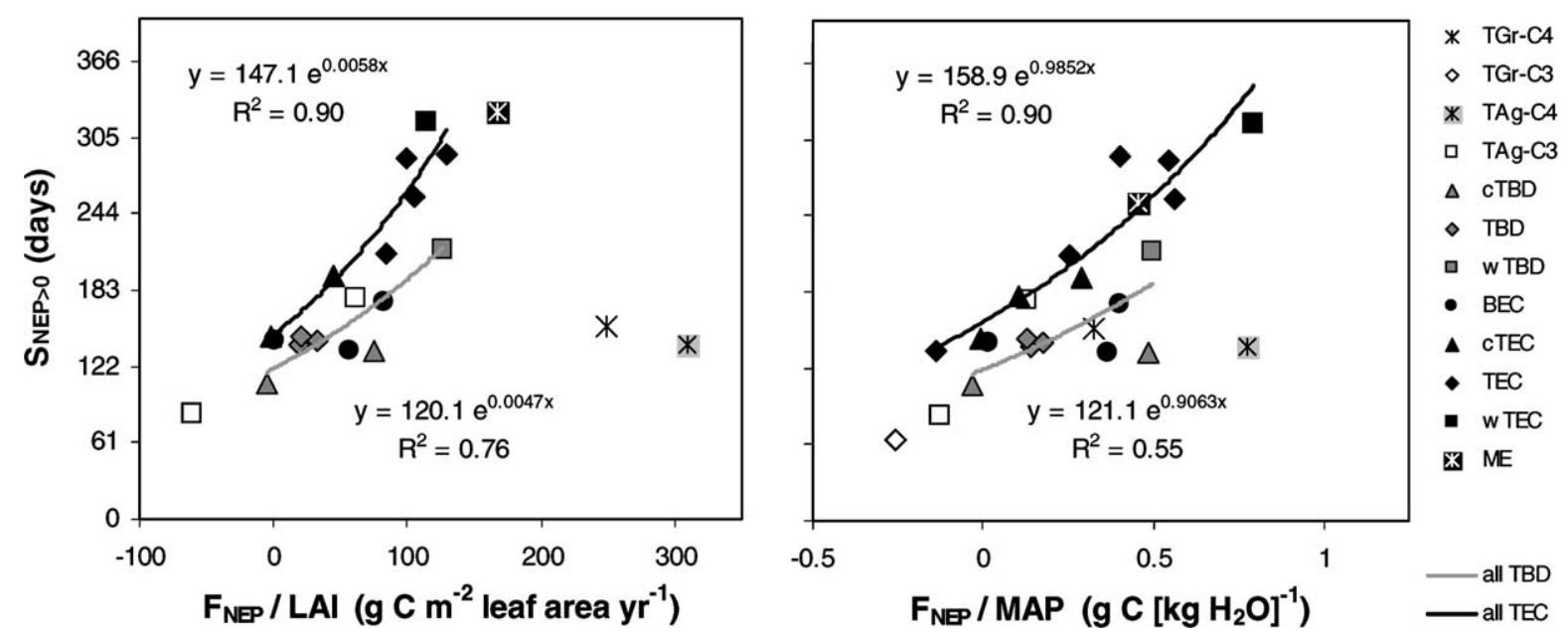

Fig. 9. Length of the season $\left(S_{\mathrm{NEP}>0}\right.$, defined as the number of days where daily $F_{\mathrm{NEP}}$, net ecosystem production, is larger than $0 \mathrm{~g} \mathrm{Cm}^{-2}$

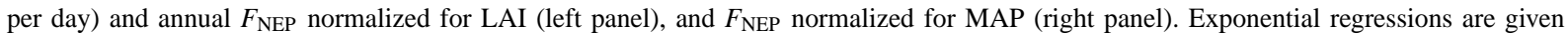
for the temperate vegetation types with the highest sample size, $n=6$ for broad-leaved deciduous forests $(\mathrm{BD}), n=10$ for evergreen conifers (EC), and available LAI and MAP values. Data of cold, intermediate, and warm temperate climate zones are pooled.

$\mathrm{C}_{3}$ grasslands and agriculture sites $\left(\mathrm{TGr}-\mathrm{C}_{3}, \mathrm{TAg}-\mathrm{C}_{3}\right)$ can be placed in the same group as TBD, though this placement might be preliminary due to the low number of sites for those vegetation types. $F_{\mathrm{NEP}}$ per leaf area of the boreal coniferous sites (BEC) fall into the same line. In terms of $F_{\mathrm{NEP}}$ per ground area however, they build a separate group (see Falge et al., 2002). $\mathrm{C}_{4}$-ecosystems show exceptional high $F_{\mathrm{NEP}}$ per leaf area, revealing the efficiency of their photochemical pathway. All together, the length of the active season is important for the carbon balance of the ecosystem, and within a vegetation type, uniform scaling factors between season length and annual $F_{\mathrm{NEP}}$ are found. Yet, disparate scaling factors have to be applied across different vegetation types.

\section{Conclusion}

We have investigated the applicability of FLUXNET data for analyzing seasonal patterns of net ecosystem carbon exchange of a series of functional vegetation types, focusing especially on their phasing and amplitudes, and compared our results of seasonal maximum values with published maximum light saturated fluxes. The analysis included boreal and temperate, deciduous and coniferous forests, Mediterranean evergreen systems, and rainforest, native and managed temperate grasslands, tundra, and $\mathrm{C}_{3}$ and $\mathrm{C}_{4}$ crops.

Remarkable parallels were found within and between the above functional vegetation types in their seasonal pattern of maximum diurnal $\mathrm{CO}_{2}$ uptake and release. Generalizations of these seasonal patterns might be of use in identification of functional types for dynamic vegetation models and inversion studies, or phenology modules for SVAT and carbon cycle models, with the possible exemption of crops and managed grasslands, where temporal variations in respiratory activity are highly irregular.

As compared to published data, seasonal maximum uptake rates show a consistent order of ecosystem flux potentials $\left(\mathrm{C}_{4}\right.$-crops $>\mathrm{C}_{3}$-crops $>$ temperate deciduous forests $>$ temperate conifers $>$ boreal conifers $>$ tundra ecosystems), supporting generalization approaches in the context of global up-scaling schemes.

Our ability to compare the results for forested ecosystems to grassland, crop or rainforest systems is constrained by the number of data sets available for the latter, where mostly only 1 or 2-year-round data sets could be compiled. To extend our findings to savanna systems, wooded grassland, shrubland, or tundra systems future studies of eddy covariance measurements should preferably investigate these systems. 
Up to now, due to the overall lack of such data sets, our understanding of how the seasonal phasing and amplitudes of respiratory and assimilatory processes affect the carbon balance of these systems is limited to the findings derived from compartment studies (chamber measurements) or model experiments.

\section{Acknowledgements}

This work is supported by the BMBF project BITÖK (PT BEO 51-0339476), and the FLUXNET program (sponsored by NASA's EOS Validation Program). It contributes to the projects CARBODATA and CARBOEUROFLUX of the European Union (supported by the EC's Fifth Framework Programme, $\mathrm{R}$ and TD contract CARBOEUROFLUX, contract no EVK2-CT-1999-0032), and the AmeriFlux program (US Department of Energy's Terrestrial Carbon Program, and NIGEC Program).

\section{References}

Aber, J.D., Ollinger, S.V., Federer, C.A., Reich, P.B., Goulden, M.L., Kicklighter, D.W., Melillo, J.M., Lathrop Jr., R.G., 1995. Predicting the effects of climate change on water yield and forest production in the northeastern United States. Climate Res. 5, 207-222.

Aubinet, M., Grelle, A., Ibrom, A., Rannik, Ü., Moncrieff, J., Foken, T., Kowalski, A.S., Martin, P.H., Berbigier, P., Bernhofer, Ch., Clement, R., Elbers, J., Granier, A., Grünwald, T., Morgenstern, K., Pilegaard, K., Rebmann, C., Snijders, W., Valentini, R., Vesala, T., 2000. Estimates of the annual net carbon and water exchange of forests: the EUROFLUX methodology. Adv. Ecol. Res. 30, 113-175.

Baldocchi, D.D., Wilson, K.B., 2001. Modeling $\mathrm{CO}_{2}$ and water vapor exchange of a temperate broadleaved forest across hourly to decadal time scales. Ecol. Model. 142, 155-184.

Baldocchi, D.D., Finnigan, J., Wilson, K., Paw U, K.T., Falge, E., 2000. On measuring net ecosystem carbon exchange over tall vegetation on complex terrain. Boundary Layer Meteorol. 96, 257-291.

Baldocchi, D., Falge, E., Wilson, K., 2001. A spectral analysis of biosphere-atmosphere trace gas flux densities and meteorological variables across hour to multi-year time scales. Agric. For. Meteorol. 107, 1-27.

Baldocchi, D., Falge, E., Gu, L., Olson, R., Hollinger, D., Running, S., Anthoni, P., Bernhofer, C., Davis, K., Evans, R., Fuentes, J., Goldstein, A., Katul, G., Law, B., Lee, X., Malhi, Y., Meyers, T., Munger, W., Oechel, W., Paw U, K.T., Pilegaard, K., Schmid, H.P., Valentini, R., Verma, S., Vesala, T., Wilson, K., Wofsy, S., 2001a. FLUXNET: a new tool to study the temporal and spatial variability of ecosystem-scale carbon dioxide, water vapor and energy flux densities. Bull. Am. Meteorol. Soc. 2415-2434.

Black, T.A., den Hartog, G., Neumann, H.H., Blanken, P.D., Yang, P.C., Russell, C., Nesic, Z., Lee, X., Chen, S.G., Staebler, R., Novak, M.D., 1996. Annual cycles of water vapour and carbon dioxide fluxes in and above a boreal aspen forest. Global Change Biol. 2, 101-111.

Black, T.A., Chen, W.J., Barr, A.G., Arain, M.A., Chen, Z., Nesic, Z., Hogg, E.H., Neumann, H.H., Yang, P.C., 2000. Increased carbon sequestration by a boreal deciduous forest in years with a warm spring. Geophys. Res. Lett. 27, 1271-1274.

Bousquet, P., Ciais, P., Peylin, P., Ramonet, M., Monfrey, P., 1999. Inverse modelling of annual atmospheric $\mathrm{CO}_{2}$ sources and sink. Part I. Method and control inversion. J. Geophys. Res. 26, 161-178.

Buchmann, N., Schulze, E.-D., 1999. Net $\mathrm{CO}_{2}$ and $\mathrm{H}_{2} \mathrm{O}$ fluxes of terrestrial ecosystems. Global Biogeochem. Cycles 13, 751-760.

Ciais, P., Tans, P.P., Trolier, M., White, J.W.C., Francey, R.J., 1995. A large northern hemisphere terrestrial $\mathrm{CO}_{2}$ sink indicated by the ${ }^{13} \mathrm{C} /{ }^{12} \mathrm{C}$ ratio of atmospheric $\mathrm{CO}_{2}$. Science $269,1098-1102$.

Craig, S.G., Holmen, K.J., Bonan, G.B., Rasch, P.J., 1998. Atmospheric $\mathrm{CO}_{2}$ simulated by the National Center for Atmospheric Research Community Climate Model. 1. Mean fields and seasonal cycles. J. Geophys. Res. D 103 (D11), 13213-13235.

DeFries, R.S., Townshend, J.R.G., 1994. NDVI-derived land cover classification at global scales. Int. J. Remote Sensing 15, 3567-3586. (special issue on global data sets).

Dorman, J.L., Sellers, P.J., 1989. A global climatology of albedo, roughness length and stomatal resistance for atmospheric general circulation models as represented by the simple biosphere model (SiB). J. Appl. Meteorol. 28, 833-855.

Easterling, D.R., Horton, B., Jones, P.D., Peterson, T.C., Karl, T.R., Parker, D.E., Salinger, M.J., Razuvayev, V., Plummer, N., Jamason, P., Folland, C.K., 1997. Maximum and minimum temperature trends for the globe. Science 277, 364-367.

Enting, I.G., Trudinger, C.M., Francey, R.J., 1995. A synthesis inversion of the concentration and delta ${ }^{13} \mathrm{C}$ of atmospheric $\mathrm{CO}_{2}$. Tellus B 47, 35-52.

Falge, E., Tenhunen, J.D., Aubinet, M., Bernhofer, C., Clement, R., Granier, A., Kowalski, A., Moors, E., Pilegaard, K., Rannik, Ü., Rebmann, C., Valentini, R., 2001a. A model-based study of carbon fluxes at ten European forest sites. In: Valentini, R. (Ed.), Fluxes of Carbon, Water and Energy of European Forests. Ecological Studies Series. Springer, Heidelberg. 113, 53-74.

Falge, E., Baldocchi, D., Olson, R.J., Anthoni, P., Aubinet, M., Bernhofer, C., Burba, G., Ceulemans, R., Clement, R., Dolman, H., Granier, A., Gross, P., Grünwald, T., Hollinger, D., Jensen, N.-O., Katul, G., Keronen, P., Kowalski, A., Ta Lai, C., Law, B.E., Meyers, T., Moncrieff, J., Moors, E., Munger, J.W., Pilegaard, K., Rannik, Ü., Rebmann, C., Suyker, A., Tenhunen, J., Tu, K., Verma, S., Vesala, T., Wilson, K., Wofsy, S., 2001b. Gap filling strategies for defensible annual sums of net ecosystem exchange. Agric. For. Meteorol. 107, 43-69.

Falge, E., Baldocchi, D., Tenhunen, J., Aubinet, M., Bakwin, P., Berbigier, P., Bernhofer, C., Burba, G., Clement, R., Davis, K.J., Elbers, J.A., Goldstein, A.H., Grelle, A., Granier, A., 
Guð̋mundsson, J., Hollinger, D., Kowalski, A.S., Katul, G., Law, B.E., Malhi, Y., Meyers, T., Monson, R.K., Munger, J.W., Oechel, W., Paw U, K.T., Pilegaard, K., Rannik, Ü., Rebmann, C., Suyker, A., Valentini, R., Wilson, K., Wofsy, S., 2002. Seasonality of ecosystem respiration and gross primary production as derived from FLUXNET measurements. Agric. For. Meteorol. 113, 53-74.

Fan, S., Gloor, M., Mahlman, J., Pacala, S., Sarmiento, J., Takahashi, T., Tans, P., 1998. A large terrestrial carbon sink in North America implied by atmospheric and oceanic carbon dioxide data and models. Science 282, 442-446.

Goulden, M.L., Wofsy, S.C., Harden, J.W., Trumbore, S.E., Crill, P.M., Gower, S.T., Fries, T., Daube, B.C., Fan, S.M., Sutton, D.J., Bazzaz, A., Munger, J.W., 1998. Sensitivity of boreal forest carbon balance to soil thaw. Science 279, 214-217.

Grime, J.P., 1993. Vegetation functional classification systems as approaches to predicting and quantifying global vegetation change. In: Solomon, A.M., Shugart, H.H. (Eds.), Vegetation Dynamics and Global Change. Chapman \& Hall, London, pp. 293-305.

Hasenauer, H., Nemani, R.R., Schadauer, K., Running, S.W., 1999. Forest growth response to changing climate between 1961 and 1990 in Austria. For. Ecol. Manage. 122, 209-219.

Heimann, M., Esser, G., Haxeltine, A., Kaduk, J., Kicklighter, D.W., Knorr, W., Kohlmaier, G.H., McGuire, A.D., Melillo, J., Moore III, B., Otto, R.D., Prentice, I.C., Sauf, W., Schloss, A., Sitch, S., 1998. Evaluation of terrestiral carbon cycle models through simulations of the seasonal cycle of atmospheric $\mathrm{CO}_{2}$ : first results of a model intercomparison study. Global Biogeochem. Cycles 12, 1-24.

Houghton, J.T., Meira Filho, L.G., Callander, B.A., Harris, N., Kattenberg, A., Maskell, K. (Eds.), 1996. Climate Change 1995-The Science of Climate Change. Cambridge University Press, Cambridge.

Jackson, R.B., Lechowicz, M.J., Li, X., Mooney, H.A., 2000. The roles of phenology, growth, and allocation in global terrestrial productivity. In: Mooney, H.A., Saugier, B., Roy, J. (Eds.), Terrestrial Global Productivity: Past, Present, and Future. Academic Press, San Diego, CA, pp. 61-82.

Keeling, C.D., Chin, J.F.S., Whorf, T.P., 1996. Increased activity of northern vegetation inferred from atmospheric $\mathrm{CO}_{2}$ observations. Nature 382, 146-149.

Kellomäki, S., Wang, K.-Y., 2000. Short-term environmental controls on carbon dioxide flux in a boreal coniferous forest: model computation compared with measurements by eddy covariance. Ecol. Model. 128, 63-88.

Keyser, A.R., Kimball, J.S., Nemani, R.R., Running, S.W., 2000. Simulating the effects of climate change in the carbon balance of North American high-latitude forests. Global Change Biol. 6, 185-195.

Kimball, J.S., Thornton, P.E., White, M.A., Running, S., 1997. Simulating forest productivity and surface-atmosphere exchange in the BOREAS study region. Tree Physiol. 17, $589-599$.

Kleidon, A., Mooney, H.A., 2000. A global distribution of biodiversity inferred from climatic constraints: results from a process-based modelling study. Global Change Biol. 6, 507-523.
Körner, C., 1994. Scaling from species to vegetation: the usefulness of functional groups. In: Schulze, E.-D., Mooney, H.A. (Eds.), Biodiversity and Ecosystem Function. Springer, New York, pp. 117-140.

Kucharik, C.J., Foley, J.A., Delire, C., Fisher, V.A., Coe, M.T., Lenters, J.D., Young-Molling, C., Ramankutty, N., Norman, J.M., Gower, S.T., 2000. Testing the performance of a dynamic global ecosystem model: water balance, carbon balance, and vegetation structure. Global Biogeochem. Cycles 14, 795-825.

Law, B., Williams, M., Anthoni, P., Baldocchi, D.D., Unsworth, M.H., 2000. Measuring and modeling seasonal variation of carbon dioxide and water vapor exchange of a Pinus ponderosa forest subject to soil water deficit. Global Change Biol. 6, 613-630.

Law, B.E., Thornton, P., Irvine, J., Anthoni, P.M., Van Tuyl, S., 2001. Carbon storage and fluxes in ponderosa pine forests at different developmental stages. Global Change Biol. 7, 755-777.

Lloyd, J., 1999. The $\mathrm{CO}_{2}$ dependence of photosynthesis, plant growth responses to elevated $\mathrm{CO}_{2}$ concentrations and their interaction with soil nutrient status. II. Temperate and boreal forest productivity and the combined effects of increasing $\mathrm{CO}_{2}$ concentrations and increased nitrogen deposition at a global scale. Funct. Ecol. 13, 439-459.

Matthews, E., 1983. Global vegetation and land use: new high resolution data bases for climate studies. J. Climate Appl. Meteorol. 22, 474-487.

Menzel, A., Fabian, P., 1999. Growing season extended in Europe. Nature 397, 659.

Meyers, T., 2001. A comparison of summertime water and $\mathrm{CO}_{2}$ fluxes over rangeland for well watered and drought conditions. Agric. For. Meteorol. 3, 205-214.

Moncrieff, J.B., Mahli, Y., Leuning, R., 1996. The propagation of errors in long term measurements of land atmosphere fluxes of carbon and water. Global Change Biol. 2, 231-240.

Myneni, R.B., Keeling, C.D., Tucker, C.J., Asrar, G., Nemani, R.R., 1997. Increased plant growth in the northern high latitudes from 1981 to 1991. Nature 386, 698-702.

Oberbauer, S.F., Starr, G., Pop, E.W., 1998. Effects of extended growing season and soil warming on carbon dioxide and methane exchange of tussock tundra in Alaska. J. Geophys. Res. 103, 29075-29082.

Peylin, P., Ciais, P., Denning, A.S., Tans, P.P., Berry, J.A., White, J.W.C., 1999. A 3-dimensional study of delta O-18 in atmospheric $\mathrm{CO}_{2}$ : contribution of different land ecosystem. Chem. Phys. Meteorol. Tellus Ser. B 51, 642-667.

Potter, C.S., Klooster, S.A., 1999. Dynamic global vegetation modelling for prediction of plant functional types and biogenic trace gas fluxes. Global Ecol. Biogeogr. 8, 473-488.

Randerson, J.T., Field, C.B., Fung, I.Y., Tans, P.P., 1999. Increases in early season ecosystem uptake explain recent changes in the seasonal cycle of atmospheric $\mathrm{CO}_{2}$ at high northern latitudes. Geophys. Res. Lett. 26, 2765-2768.

Rayner, P.J., Enting, I.G., Francey, R.J., Langenfelds, R., 1999. Reconstructing the recent carbon cycle from atmospheric $\mathrm{CO}_{2}$, $\mathrm{d}^{13} \mathrm{C}$ and $\mathrm{O}_{2} / \mathrm{N}_{2}$ observations. Tellus $\mathrm{B} 51,213-232$. 
Reich, P.B., Walters, M.B., Ellsworth, D.S., 1997. From tropics to tundra: global convergence in plant functioning. Proc. Natl. Acad. Sci. 94, 13730-13734.

Running, S.W., Baldocchi, D.D., Turner, D., Gower, S.T., Bakwin, P., Hibbard, K., 1999. A global terrestrial monitoring network, scaling tower fluxes with ecosystem modeling and EOS satellite data. Remote Sensing Environ. 70, 108-127.

Schulze, E.-D., Lloyd, J., Kelliher, F.M., Wirth, C., Rebmann, C., Luhker, B., Mund, M., Knohl, A., Milyukova, I.M., Schulze, W., Ziegler, W., Varlagin, A.B., Sogachev, A.F., Valentini, R., Dore, S., Grigoriev, S., Kolle, O., Panfyorov, M.I., Tchebakova, N., Vygodskaya, N.N., 1999. Productivity of forests in the Eurosiberian boreal region and their potential to act as a carbon sink-a synthesis. Global Change Biol. 5 (6), 703-722.

Sellers, P.J., Randall, D.A., Collatz, G.J., Berry, J.A., Field, C.B., Dazlich, D.A., Zhang, C., Collelo, G.D., Bounoua, L., 1996. A revised land surface parameterization $(\mathrm{SiB} 2)$ for atmospheric GCMs. Part I. Model formulation. J. Climate 9, 676-705.

Smith, T.M., Shugart, H.H., Woodward, F.I. (Eds.), 1997. Plant Functional Types. Cambridge University Press, New York.

Solomon, A.M., Shugart, H.H. (Eds.), 1993. Vegetation Dynamics and Global Change. Chapman \& Hall, New York, 338 pp.

Starr, G., Oberbauer, S.F., Pop, E.W., 2000. Effects of extended growing season and soil warming on phenology and physiology of Polygonum bistorta. Global Change Biol. 6, 357-369.

Valentini, R. (Ed.), 2002. Fluxes of Carbon, Water and Energy of European Forests, Ecological Studies Series, Springer Verlag, Heidelberg, (in press).
Walker, B.H., 1997. Functional types in non-equilibrium ecosystems. In: Smith, T.M., Shugart, H.H., Woodward, F.I. (Eds.), Plant Functional Types. Cambridge University Press, New York, pp. 91-103.

White, M.A., Thornton, P.E., Running, S.W., 1997. A continental phenology model for monitoring vegetation responses to interannual climatic variability. Global Biogeochem. Cycles 11, 217-234.

White, M.A., Running, S.W., Thornton, P.E., 1999. The impact of growing-season length variability on carbon assimilation and evapotranspiration over 88 years in the eastern US deciduous forest. Int. J. Biometeorol. 42, 139-145.

Williams, M., Eugster, W., Rastetter, E.B., McFadden, J.P., Chapin Jr., F.S., 2000. The controls on net ecosystem productivity along an Arctic transect: a model comparison with flux measurements. Global Change Biol. 6 (Suppl. 1), 116-126.

Wilson, K.B., Baldocchi, D.D., Hanson, P.J., 2000. Spatial and seasonal variability of photosynthesis parameters and their relationship to leaf nitrogen in a deciduous forest. Tree Physiol. 20, 565-587.

Wilson, K.B., Baldocchi, D.D., Hanson, P.J., 2001. Leaf age affects the seasonal pattern of photosynthetic capacity and net ecosystem exchange of carbon in a deciduous forest. Plant Cell Environ. 24, 571-583.

Woodward, F.I., Kelly, C.K., 1997. Plant functional types: towards a definition by environmental constraints. In: Smith, T.M., Shugart, H.H., Woodward, F.I. (Eds.), Plant Functional Types. Cambridge University Press, New York, pp. 47-65. 